\title{
Dennstaedtiaceae (Polypodiopsida) no estado de Minas Gerais, Brasil ${ }^{1}$
}

\author{
Dennstaedtiaceae (Polypodiopsida) in Minas Gerais, Brasil
}

\author{
Francine Costa Assis ${ }^{2}$ \& Alexandre Salino ${ }^{2,3}$
}

\begin{abstract}
Resumo
Dennstaedtiaceae Pic. Serm. sensu lato é formada por cerca de 20 gêneros e 175 espécies. A família é caracterizada pelo caule ereto, raramente arborescente, curto a longo-reptante, com tricomas e/ou escamas, folhas geralmente pinadas, raro simples, soros indusiados e marginais, submarginais ou raramente abaxiais, esporângios curto a longo-pedicelados, ânulo interrompido pelo pedicelo, esporos sem clorofila. Foram encontrados no estado de Minas Gerais oito gêneros e 24 espécies de Dennstaedtiaceae: Blotiella lindeniana (Hook.) R.M. Tryon, Dennstaedtia cicutaria (Sw.) T. Moore, D. cornuta (Kaulf.) Mett., D. dissecta (Sw.) T. Moore, D. globulifera (Poir.) Hieron., Histiopteris incisa (Thunb.) J. Sm., Hypolepis aquilinaris (Fée) Christ, H. repens (L.) C. Presl, H. stolonifera Fée, H. mitis Kunze, Lindsaea arcuata Kunze, L. bifida (Kaulf.) Mett. ex Kuhn, L. botrychioides St.-Hil., L. divaricata Klotzsch, L. guianensis ssp. lanceastrum K.U. Kramer, L. lancea (L.) Bedd. var. lancea, L. ovoidea Fée, L. quadrangularis Raddi ssp. quadrangularis, $L$. stricta (Aubl.) Dryand. var. stricta, L. virescens Sw. var. virescens, Paesia glandulosa (Sw.) Kuhn, Pteridium arachnoideum (Kaulf.) Maxon, Saccoloma elegans Kaulf. e S. inaequale (Kunze) Mett. São apresentadas descrições, chaves de identificação, ilustrações, comentários e distribuição geográfica dos táxons.

Palavras-chave: florística, pteridófitas, taxonomia.

\section{Abstract}

Dennstaedtiaceae Pic. Serm. sensu lato is a family contains about 20 genera and 175 species. The family is characterized by stem erect, short or very long-creeping, bearing trichomes or scales, or both, leaves pinnate or rarely simple, indusiate and marginal, submarginal or rarely abaxial sori, sporangia short to usually long-stalked, annulus interrupted by the stalk, spores lacking chlorophyll. Eight genera and twenty four species were found: Blotiella lindeniana (Hook.) R.M. Tryon, Dennstaedtia cicutaria (Sw.) T. Moore, D. cornuta (Kaulf.) Mett., D. dissecta (Sw.) T. Moore, D. globulifera (Poir.) Hieron., Histiopteris incisa (Thunb.) J. Sm., Hypolepis aquilinaris (Fée) Christ, H. repens (L.) C. Presl., H. stolonifera Fée, H. mitis Kunze, Lindsaea arcuata Kunze, L. bifida (Kaulf.) Mett. ex Kuhn, L. botrychioides St.-Hil., L. divaricata Klotzsch, L. guianensis ssp. lanceastrum K.U. Kramer, L. lancea (L.) Bedd. var. lancea, L. ovoidea Fée, L. quadrangularis Raddi ssp. quadrangularis, L. stricta (Aubl.) Dryand. var. stricta, L. virescens Sw. var. virescens, Paesia glandulosa (Sw.) Kuhn, Pteridium arachnoideum (Kaulf.) Maxon, Saccoloma elegans Kaulf., and S. inaequale (Kunze) Mett. Descriptions, identification keys, illustrations, geographical distribution, and comments of taxa are provided.
\end{abstract}

Key words: ferns, floristics, taxonomy.

\section{Introdução}

Dennstaedtiaceae Pic. Serm. é formada por cerca de 20 gêneros e 175 espécies (Tryon \& Stolze 1989). Está amplamente distribuída no mundo e, embora seja predominantemente pantropical, possui espécies boreais ou de regiões temperadas austrais (Tryon \& Stolze 1989). A família pode ser caracterizada pelo caule ereto, raramente arborescente, curto a longo-reptante, coberto por tricomas e/ou escamas, folhas geralmente pinadas, raramente simples, soros indusiados e marginais, submarginais ou raramente abaxiais, esporângios curto a geralmente longo-pedicelados, ânulo interrompido pelo pedicelo e esporos sem clorofila (Tryon \& Tryon 1982).

\footnotetext{
${ }^{1}$ Parte de dissertação de Mestrado, ICB/UFMG.

${ }^{2}$ Universidade Federal de Minas Gerais, Instituto de Ciências Biológicas, Depto. Botânica. C. P. 486, 30123-970, Belo Horizonte, MG, Brasil.

${ }^{3}$ Autor para correspondência: salinobh@gmail.com.
} 
Smith et al. (2006) apresentam uma nova classificação para as famílias e gêneros de pteridófitas, baseada numa hipótese filogenética que utiliza tanto dados morfológicos quanto moleculares. Segundo Smith et al. (2006) Dennstaedtiaceae sensu lato deve ser segregada em Dennstaedtiaceae sensu stricto (ca. 11 gêneros), Lindsaeaceae (ca. oito gêneros) e Saccolomataceae (apenas um gênero). Apesar destas recentes análises, o presente estudo utilizou a circunscrição de Dennstaedtiaceae sensu lato adotada por Tryon \& Tryon (1982).

Informações disponíveis sobre espécies brasileiras de Dennstaedtiaceae podem ser encontradas na Flora brasiliensis (Baker 1870), Flora Ilustrada Catarinense (Sehnem 1972), ou mesmo mais recentemente em Kieling-Rubio \& Windisch 2002 para o estado do Rio Grende do Sul. Tais informações também podem ser encontradas em trabalhos com enfoque mais regional como Ilha de Maracá (Edwards 1998), Flora do Maciço da Juréia (Prado 2004a), Parque Estadual das Fontes do Ipiranga - SP (Prado 2004b), Reserva do Rio das Pedras - Mangaratiba (Mynssen \& Windisch 2004), Reserva Ducke - Manaus (Prado 2005) e Parque Estadual de Vila Velha - Ponta Grossa (Schwartsburd \& Labiak 2007), nos quais somente algumas espécies são tratadas, o mesmo ocorrendo para Minas Gerais nos trabalhos da Serra do Cipó (Prado \& Windisch 1996), Grão Mogol (Prado \& Labiak 2003) e Estação Ecológica do Panga - Uberlândia (Arantes et al. 2008).

O objetivo desse trabalho foi realizar um estudo taxonômico de Dennstaedtiaceae sensu lato no estado de Minas Gerais, elaborando descrições, chaves de identificação, ilustrações dos táxons e comentários taxonômicos, contribuindo assim para a ampliação do conhecimento da flora pteridofítica para o estado.

\section{Material e Métodos}

$O$ presente estudo foi realizado com base em amostras coletadas nas regiões noroeste e norte de Minas, Baixo Vale do Jequitinhonha, Central Mineira, Triângulo Mineiro, Vale do Rio Doce, Zona da Mata, Sudeste e Sul de Minas Gerais, bem como em material proveniente dos herbários BHCB, F, HB, HUFU, MBM, MBML, OUPR, R, RB, SJRP e SPF (510 espécimes). As siglas dos herbários seguem Holmgren et al. (1990). As amostras foram coletadas e preparadas segundo técnicas usuais de herborização. Os espécimes testemunhos foram depositados no acervo do herbário BHCB. A lista completa dos materiais examinados e comentários de cada espécie encontram-se disponíveis em Assis (2008).

A descrição da família foi baseada em Tryon \& Tryon (1982), Tryon \& Stolze (1989) e Kramer (1990), apresentando amplitude nacional.

As descrições das espécies foram elaboradas exclusivamente com base no material examinado. As medidas das estruturas foram realizadas em materiais férteis; o comprimento das pinas corresponde às do terço médio da lâmina; o comprimento das pínulas refere-se às do terço médio das pinas medianas; a largura das pinas e pínulas foi medida na parte média. A medida do diâmetro do caule foi realizada próxima ao pecíolo e, para o diâmetro do pecíolo, a medida foi feita na base. Para a descrição da morfologia em geral, foram utilizados os termos propostos no glossário de Lellinger (2002).

No tratamento taxonômico, os táxons estão arranjados em ordem alfabética. As abreviaturas de autores dos táxons estão de acordo com Pichi Sermolli (1996).

\section{Resultados e Discussão}

Tratamento taxonômico

Dennstaedtiaceae Pic. Serm., Webbia 24: 704. 1970.

Plantas terrestres ou rupícolas, raro epífitas. Caule ereto, raramente arborescente, curto a longoreptante, com tricomas e/ou escamas. Folhas ca. 20 $\mathrm{cm}$ a $7 \mathrm{~m}$ compr., raro $12 \mathrm{~m}$ compr., de vernação circinada, geralmente pinadas, raro simples e cordadas a sagitadas, geralmente monomorfas; nervuras livres a completamente anastomosadas, sem vênulas livres nas aréolas. Soros marginais, submarginais, ou raramente abaxiais, nas extremidades das nervuras ou sobre uma comissura vascular; indúsio em forma de taça ou bolsa, ou formado por segmento modificado da margem da lâmina revoluta sobre os esporângios, ou indúsio abaxial estendido lateralmente, ou ainda um indúsio marginal bem desenvolvido e outro interno abaxial menos desenvolvido; esporângios curtos a geralmente longo-pedicelados, com ângulo longitudinal a levemente oblíquo, ânulo interrompido pelo pedicelo, isosporados, esporos monoletes ou triletes, sem clorofila. 


\section{Chave de identificação para os gêneros de Dennstaedtiaceae sensu lato em Minas Gerais}

1. Uma única nervura em cada soro.

2. Caule ereto, com escamas

8. Saccoloma

2'. Caule reptante, sem escamas.

3. Esporos monoletes; indúsio formado pela margem da lâmina revoluta e modificada

4. Hypolepis

3'. Esporos triletes; indúsio em forma de taça ou bolsa

2. Dennstaedtia

1'. Duas ou mais nervuras em cada soro.

4. Pinas ou pínulas dimidiadas, flabeladas ou ovadas

5. Lindsaea

4'. Pinas ou pínulas lineares, elípticas, lanceoladas, raro deltóides.

5. Nervuras livres.

6. Lâmina com tricomas glandulares

6. Paesia

6'. Lâmina sem tricomas glandulares

7. Segmentos estéreis e porção estéril de segmentos férteis com margem modificada similar ao indúsio; indúsio abaxial presente 7. Pteridium

7'. Segmentos estéreis e porção estéril de segmentos férteis com margem não modificada similar ao indúsio, somente porção fértil do segmento com margem modificada em indúsio; indúsio abaxial ausente

1. Blotiella

5'. Nervuras anastomosadas.

8. Caule com escamas; lâmina geralmente glabra, usualmente glauca na face abaxial

8'. Caule sem escamas; lâmina sempre pilosa, não glauca na face abaxial 3. Histiopteris 1. Blotiella

1. Blotiella R.M. Tryon, Contr. Gray Herb. 191: 96. 1962.

Blotiella é um dos poucos gêneros de pteridófitas fortemente centrados na África (ca. 15 espécies), apresentando uma única espécie na região Neotropical (Tryon \& Tryon 1982; Kramer 1990).

1.1. Blotiella lindeniana (Hook.) R.M. Tryon, Contr. Gray Herb. 191: 99. 1962. Lonchitis lindeniana Hook. Sp. Fil. 2: 56. $1851 . \quad$ Fig. 1a-c

Plantas terrestres; caule reptante, 8,24-10,95 mm diâm., piloso ou pubescente com tricomas catenados. Folhas 135,8-180,5 cm compr.; pecíolo 32-54,6 $\times 0,70$ $0,89 \mathrm{~cm}$, sulcado adaxialmente, com tricomas aciculares, catenados ou clavados; lâmina 103,8125,9 cm compr., 2-pinado-pinatífida, membranácea, lanceolada ou elíptica, ápice agudo ou cuneado; raque sulcada adaxialmente, com tricomas aciculares, catenados e clavados; pinas 17,2 $-33,3 \mathrm{~cm}$ compr., sésseis, lanceoladas a elípticas, ápice cuneado, às vezes caudado; costa sulcada adaxialmente, pilosa ou pubescente; pínulas 2,1-5,2×0,99-1,7 cm, sésseis, lineares, ápice cuneado, às vezes caudado, margem crenada, as basais reduzidas ou ausentes no lado acroscópico, reduzidas ou não no lado basioscópico; cóstula sulcada ou não adaxialmente, pilosa ou pubescente; indumento de tricomas aciculares e clavados na costa, cóstula, tecido laminar e margens dos segmentos, tricomas catenados na costa e cóstula, nervuras glabras. Soros reniformes, nos enseios ou nos lados acroscópico e basioscópico; indúsio membranáceo, margem crenada, pubescente com tricomas aciculares ou catenados.

Material examinado: Santa Maria do Salto, Fazenda Duas Barras, 16²4'16,5"S e 4003'27,4”'W, X.2003, A. Salino et al. 9236 (BHCB). Simonésia, RPPN Mata do Sossego, 2004'2,0"'S e 42 04'40,4”'W, V.2006, A. Salino et al. 11027 (BHCB).

Segundo Tryon \& Stolze (1989), Blotiella lindeniana apresenta nervuras completamente anastomosadas, entretanto, no material analisado ocorrem nervuras anastomosadas e livres. Em Minas Gerais, a espécie é considerada ameaçada de extinção.

Blotiella lindeniana ocorre no Caribe, Costa Rica, Venezuela, Colômbia, Bolívia e Brasil (Tryon \& Tryon 1982). No Brasil ocorre nos estados de Minas Gerais, Espírito Santo, Rio de Janeiro, São Paulo e Santa Catarina (Schwartsburd 2010). Em Minas Gerais ocorre geralmente em locais muito úmidos, em floresta ombrófila densa montana, entre 750 e $1600 \mathrm{~m}$ de altitude.

2.Dennstaedtia Bernh., J. Bot. 1800(2): 124. 1800 [1801].

Dennstaedtia é um gênero tropical e extratropical, com ca. 45 espécies, sendo 12 delas encontradas na América (Tryon \& Tryon 1982). 

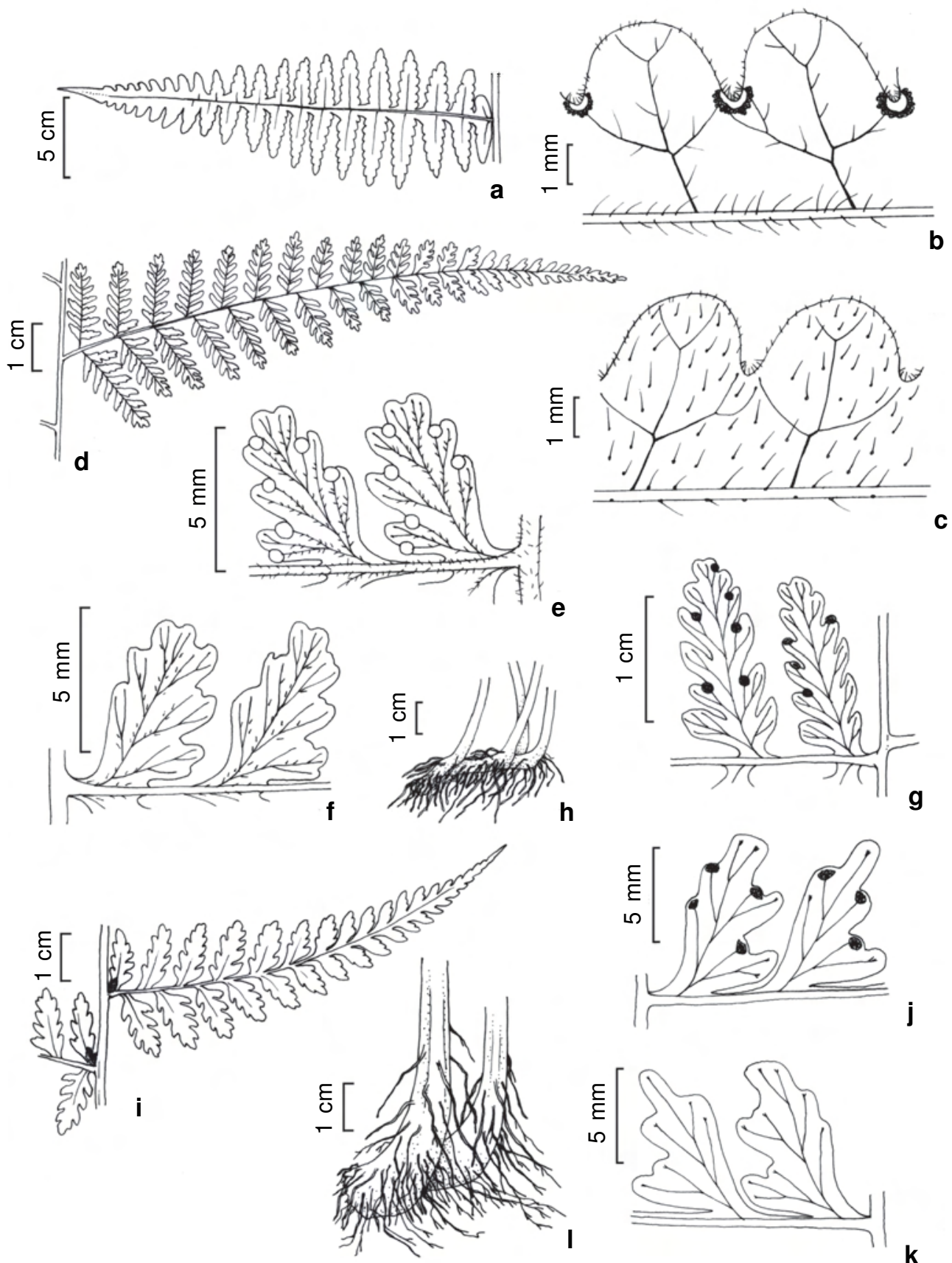

Figura 1 - a-c. Blotiella lindeniana (A. Salino 9236) - a. pina mediana; b. detalhe da face abaxial dos segmentos e cóstula; c. detalhe da face adaxial dos segmentos e da cóstula. d-f. Dennstaedtia cicutaria (T.E. Almeida 237) - d. pina mediana; e. detalhe da face abaxial dos segmentos e da cóstula; f. detalhe da face adaxial dos segmentos e da cóstula. g-h. Dennstaedtia cornuta (A. Salino 12539) - g. detalhe da face abaxial dos segmentos e da cóstula; h. detalhe da base do pecíolo e caule. i-1. Dennstaedtia dissecta (A. Salino 2227) - i. pinas medianas com gemas na base; j. detalhe da face abaxial dos segmentos e da cóstula; $k$. detalhe da face adaxial dos segmentos e da cóstula; l. detalhe da base do pecíolo.

Figure 1 - a-c. Blotiella lindeniana (A. Salino 9236) - a. medial pinna; b. detail of the abaxial surface of segments and costule; c. detail of the adaxial surface of segments and costule. d-f. Dennstaedtia cicutaria (T.E. Almeida 237) - d. medial pinna; e. detail of the abaxial surface of segments and costule; f. detail of the adaxial surface of segments and costule. g-h. Dennstaedtia cornuta (A. Salino 12539) - g. detail of the abaxial surface of segments and costule; h. detail of petiole base and stem. i-1 Dennstaedtia dissecta (A. Salino 2227) - i. medial pinnae with buds; j. detail of the abaxial surface of segments and costule; $\mathrm{k}$. detail of the adaxial surface of segments and costule; 1. detail of petiole base. 


\section{Chave de identificação para as espécies de Dennstaedtia em Minas Gerais}

1. Eixo dos penúltimos segmentos com aletas herbáceas no lado basioscópico da face adaxial perpendiculares ao plano do segmento; caule piloso 2.4. D. globulifera

1'. Eixo dos penúltimos segmentos sem aletas herbáceas; caule glabro ou pubescente.

2. Com gemas nas pinas e pínulas; lâmina membranácea a papirácea; pínulas sésseis.

3. Base do pecíolo com raízes; pinululas $0,34-0,52 \mathrm{~cm}$ de largura 2.3. D. dissecta

3'. Base do pecíolo sem raízes; pinululas $0,15-0,28 \mathrm{~cm}$ de largura 2.2. D. cornuta

2'. Sem gemas nas pinas e pínulas; lâmina cartácea; pínulas pecioluladas 2.1. D. cicutaria

2.1.Dennstaedtia cicutaria (Sw.) T. Moore, Index Fil. 97. 1857. Dicksonia cicutaria Sw., J. Bot. 1800(2): 91.1801.

Fig. 1d-f

Plantas terrestres; caule reptante, 8,18 $12,23 \mathrm{~mm}$ diâm., pubescente com tricomas aciculares e catenados, ou glabro. Folhas $159,5-250,5 \mathrm{~cm}$ compr.; pecíolo $69-150 \times 0,68-1,24 \mathrm{~cm}$, sulcado adaxialmente, sem raízes na base, pubescente com tricomas aciculares; lâmina 90,5-100,5 cm compr., 2-pinado-pinatífida a 3-pinado-pinatissecta, cartácea, lanceolada a elíptica, ápice agudo; raque sulcada adaxialmente, pubescente com tricomas aciculares e catenados; pinas 18,4-54 cm compr., pecioluladas, lanceoladas a lineares, ápice cuneado a agudo, sem gemas; costa sulcada adaxialmente, pubescente ou pilosa; pínulas 2,6-9 ×0,73-2 cm, pecioluladas, lanceoladas a lineares, ápice cuneado a agudo, às vezes caudado, as basais não reduzidas, sem gemas; cóstula sulcada adaxialmente, pubescente ou pilosa; pinululas $0,89-1,11 \times 0,32$ $0,45 \mathrm{~cm}$, sésseis, sem aletas na base, lineares, dimidiadas ou quadrilaterais, ápice redondo, margem crenada a inteira, plana ou recurvada, glabra, as basais não reduzidas; nervuras bifurcadas, as estéreis clavadas no ápice; indumento de tricomas catenados na costa, cóstula, tecido laminar e nervuras. Soros oblongos ou arredondados; indúsio em forma de bolsa, membranáceo, glabro.

Material examinado: Patos de Minas, Cascata, 1.IX.1935, A.P. Duarte 3077 (RB). Sabará, RPPN de Cuiabá, Base da Serra da Piedade, $19^{\circ} 51^{\prime} 8,7^{\prime \prime}$ 'S e 434’38,'”, 18.VII.2006, T.E. Almeida \& D.T. Souza 237 (BHCB). São Roque de Minas, Parque Nacional da Serra da Canastra, Casca d'Anta, $20^{\circ} 18^{\prime} 20^{\prime \prime S}$ e 46³1'12,8”'W, 14.VII.1997, A. Salino 3196 (BHCB).

Dennstaedtia cicutaria ocorre no México, América Central, Grandes Antilhas e Venezuela até a Argentina (Mickel \& Smith 2004). No Brasil ocorre nos estados do Pará, Ceará, Mato Grosso, Minas Gerais, Espírito Santo, Rio de Janeiro, São Paulo, Paraná e Santa Catarina (Schwartsburd 2010). Em
Minas Gerais ocorre geralmente no interior de formações florestais como matas de galeria, em floresta estacional semidecidual montana e floresta ombrófila densa montana, entre 700 e $1200 \mathrm{~m}$ de altitude.

2.2. Dennstaedtia cornuta (Kaulf.) Mett., Ann. Sci. Nat. 5. 2: 260. 1864. Dicksonia cornuta Kaulf., Enum. Fil. 227. 1824.

Fig. 1g-h

Plantas rupícolas ou terrestres; caule geralmente ascendente ou reptante com ápice elevado, 3,46-1,77 mm diâm., glabro. Folhas 39,5$142,5 \mathrm{~cm}$ compr.; pecíolo 15,5-47 ×0,17-0,74 cm, sulcado adaxialmente, sem raízes na base, pubescente com tricomas catenados; lâmina 2498,5 cm compr., 2-pinada a 3-pinado-pinatífida, membranácea a papirácea, lanceolada a elíptica, ápice agudo a cuneado; raque sulcada adaxialmente, pubescente com tricomas catenados; pinas $(3,8) 10,4-27,6 \mathrm{~cm}$ compr., sésseis, elípticas a lineares, ápice cuneado-caudado, ou redondo, com gemas pubescentes com tricomas catenados; costa sulcada adaxialmente, pubescente ou glabra; pínulas $(0,64) 1,2-3,2 \times 0,42-1 \mathrm{~cm}$, sésseis, lanceoladas, lineares ou elípticas, ápice redondo ou cuneado, caudado ou não, as basais reduzidas ou não, com gemas pubescentes com tricomas catenados; cóstula sulcada ou não adaxialmente, pubescente ou glabra; pinululas $0,39-0,61 \times 0,15$ $0,28 \mathrm{~cm}$, sésseis, sem aletas na base, ovadas, ápice redondo ou agudo, margem inteira ou levemente crenada, geralmente plana, glabra, as basais reduzidas ou não; nervuras geralmente bifurcadas, as estéreis clavadas no ápice; indumento de tricomas catenados na costa, cóstula, tecido laminar e nervuras, ou tecido laminar e nervuras glabros. Soros oblongos ou arredondados; indúsio em forma de bolsa, membranáceo, glabro.

Material examinado selecionado: Conceição do Mato Dentro, Parque Natural Municipal do Ribeirão do Campo, $19^{\circ} 06^{\prime} 19,4^{\prime \prime}$ e $43^{\circ} 34^{\prime} 4,9^{\prime \prime} \mathrm{W}, 30 . \mathrm{V} .2003$, A. Salino et al. 8749 (BHCB). Lambari, Parque Estadual de Nova Baden,

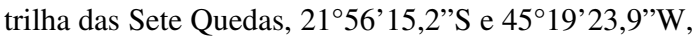


13.VII.2007, A. Salino et al. 12539 (BHCB). Santa Maria do Salto, Fazenda Duas Barras, $16^{\circ} 24^{\prime} 16,5$ "S e 4003'27,4”'W, 10.X.2003, A. Salino et al. 9261 (BHCB).

Dennstaedtia cornuta apresenta todos os eixos castanho-escuros.

A espécie ocorre no México, América Central e Venezuela até a Bolívia (Mickel \& Smith 2004). A distribuição no Brasil é incerta, porém há um registro para a Bahia (Matos 2009). Em Minas Gerais ocorre geralmente em locais muito úmidos, à margem de cursos d'água, muitas vezes sobre rochas úmidas junto à cachoeiras, em Floresta Ombrófila Densa Submontana e Montana (em fundo de vale e interflúvios) e matas de galeria, entre 620 e $1600 \mathrm{~m}$ de altitude.

2.3. Dennstaedtia dissecta (Sw.) T. Moore, Index Fil. 305. 1861. Polypodium dissectum Sw., Prodr. 134. 1788.

Fig. 1i-1

Plantas terrestres, raro rupícolas; caule reptante, 2,02-18,67 mm diâm., pubescente com tricomas catenados ou glabro. Folhas $35-316 \mathrm{~cm}$ compr.; pecíolo $11-118 \times 0,21-1,12 \mathrm{~cm}$, sulcado adaxialmente, com raízes na base, pubescente com tricomas catenados, clavados ou aciculares; lâmina 53,5-198 cm compr., 2-pinada a 3-pinado-pinatífida, membranácea a papirácea, lanceolada a elíptica, ápice agudo a cuneado, às vezes caudado; raque sulcada adaxialmente, pubescente com tricomas catenados; pinas 5,9-56,3 cm compr., sésseis, ou curtopecioluladas, elípticas, lanceoladas ou lineares, ápice cuneado-caudado, agudo, ou redondo, com gemas pubescentes com tricomas catenados; costa sulcada adaxialmente, pubescente ou glabra; pínulas $0,53-$ $10,1 \times 0,79-9,18 \mathrm{~cm}$, sésseis, lanceoladas ou lineares, ápice redondo ou cuneado, às vezes caudado, as basais reduzidas ou não, com gemas pubescentes com tricomas catenados; cóstula sulcada ou não adaxialmente, pubescente ou glabra; pinululas $0,55-$ $1,06 \times 0,34-0,52 \mathrm{~cm}$, sésseis, sem aletas na base, oblongas, ápice redondo ou quadrangular, margem crenada a inteira, plana às vezes recurvada, glabra, as basais reduzidas ou não; nervuras geralmente bifurcadas, às vezes 2-3-bifurcadas, as estéreis clavadas no ápice; indumento de tricomas catenados na costa, cóstula, tecido laminar e nervuras, ou tecido laminar e nervuras glabros. Soros arredondados; indúsio em forma de bolsa, membranáceo, glabro. Material examinado selecionado: Aiuruoca, Vale do Matutu, RPPN do Matutu, Cachoeira do Fundo, 22 10'02'S e 4454'49,9'W, 12.X.2004, A. Salino et al. 9816 (BHCB). Caratinga, Estação Biológica de Caratinga, Jaó, 24.III.2000, A. Salino 5120 (BHCB).
Catas Altas, Parque Natural do Caraça, Mata do Engenho, $20^{\circ} 07^{\prime} \mathrm{S}$ e $43^{\circ} 27^{\prime} \mathrm{W}, 20 . \mathrm{XI} .2004$, N.F.O. Mota et al. 78 (BHCB).

Dennstaedtia dissecta ocorre no México, América Central, Antilhas, Trinidad a Colômbia, Brasil, Bolívia e Paraguai (Tryon \& Stolze 1989). No Brasil ocorre nos estados da Bahia, Minas Gerais, Rio de Janeiro, São Paulo, Paraná, Santa Catarina e Rio Grande do Sul (Schwartsburd 2010). Em Minas Gerais ocorre geralmente em locais muito úmidos, muitas vezes até alagados, em matas de galeria e ciliares, floresta estacional semidecidual submontana, montana e altomontana e floresta ombrófila densa montana, entre 370 e 1900 m de altitude.

2.4. Dennstaedtia globulifera (Poir.) Hieron., Bot. Jahrb. Syst. 34. 455. 1904. Polypodium globuliferum Poir.Encycl. 5: 554. 1804.

Fig. 2a-c

Plantas terrestres, caule reptante, 1,89-12,69 mm diâm., piloso com tricomas catenados ou aciculares. Folhas 109-323,8 cm compr.; pecíolo 48-130×0,36$0,95 \mathrm{~cm}$, sulcado adaxialmente, sem raízes na base, piloso com tricomas catenados e aciculares, pubescente com tricomas catenados; lâmina 61193,8 cm compr., 3-pinada, raro 2-pinado-pinatífida, membranácea, lanceolada ou elíptica, ápice agudo ou lanceado; raque sulcada adaxialmente, pubescente, pilosa ou não com tricomas catenados; pinas 19$42,1 \mathrm{~cm}$ compr., pecioluladas ou curto-pecioluladas, elípticas, lanceoladas ou lineares, ápice cuneado ou agudo, caudado ou não, sem gemas; costa sulcada adaxialmente, pubescente ou glabra; pínulas 2,4-8,4 $\times 0,48-2 \mathrm{~cm}$, pecioluladas a sésseis, lanceoladas a lineares, ápice cuneado, agudo, ou redondo, às vezes caudado, as basais reduzidas ou não, sem gemas; cóstula sulcada adaxialmente, pubescente ou glabra; pinululas 0,50-0,99 $\times 0,24-0,51 \mathrm{~cm}$, sésseis, com aletas herbáceas no lado adaxial e na base da penúltima pinulula, ovadas ou dimidiadas, ápice redondo, margem crenada, recurvada ou não, glabra, as basais reduzidas ou não; nervuras bifurcadas, raro simples, estéreis clavadas no ápice; indumento de tricomas aciculares na costa e cóstula, tricomas catenados na costa, cóstula, tecido laminar e nervuras, ou tecido laminar e nervuras glabros. Soros arredondados ou oblongos; indúsio em forma de taça, membranáceo, pubescente com tricomas catenados, principalmente na base.

Material examinado selecionado: Alto Caparaó, Parque Nacional do Caparaó, XI.2006, A. Salino et al. 11421 (BHCB). Januária, vale do Rio Peruaçu, 1507’23”'S e 4414'34”'W, 20.VII.1997, A. Salino 3251 (BHCB). Marliéria, Parque Estadual do Rio Doce, trilha do Vinhático, 29.III.1996, A. Salino 2666 (BHCB). 

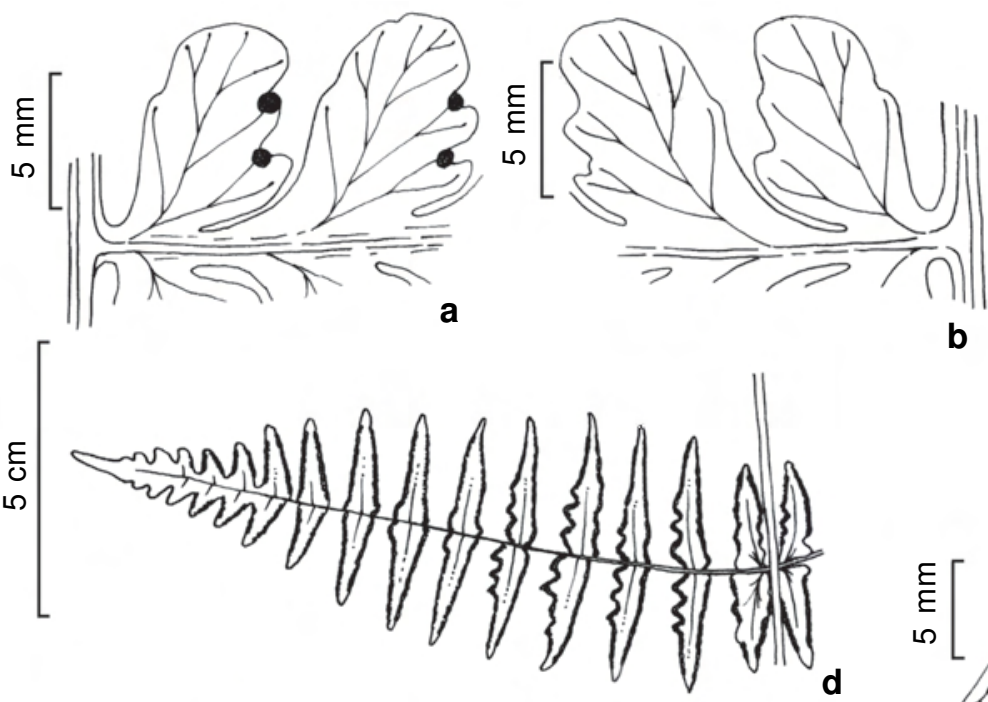

b
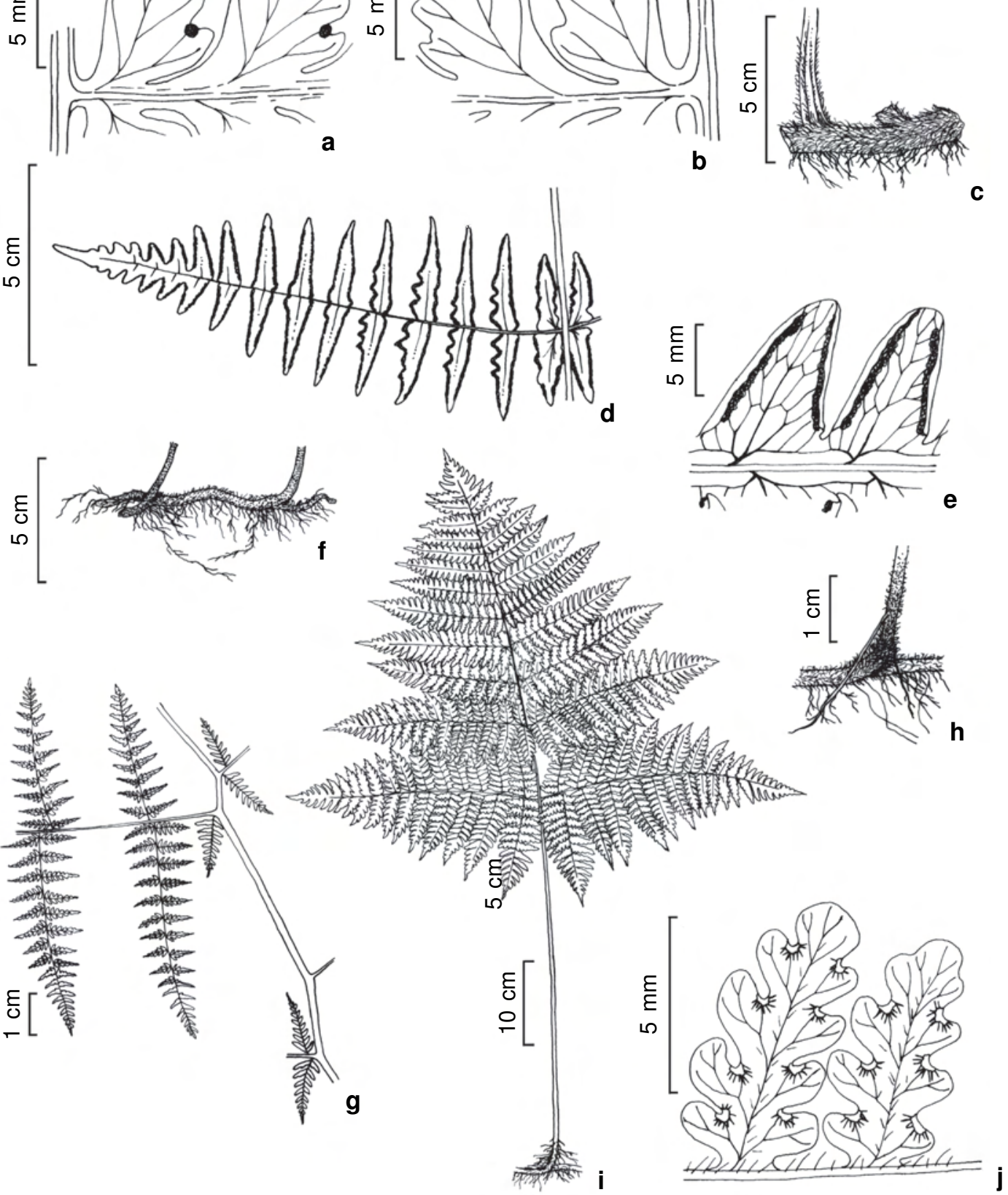

Figura 2 - a-c. Dennstaedtia globulifera (A. Salino 9569) - a. detalhe da face abaxial dos segmentos e da cóstula; b. detalhe da face adaxial dos segmentos e da cóstula; c. detalhe da base do pecíolo e caule. d-f. Histiopteris incisa (F.C. Assis 01) - d. pina mediana; e. detalhe da face abaxial dos segmentos e da cóstula; f. detalhe da base do pecíolo e caule. g-h. Hypolepis aquilinaris (J.B. Figueiredo 481) - g. detalhe da face abaxial da raque, costa e pínulas; h. detalhe da base do pecíolo e caule. i-j Hypolepis mitis (A. Salino 12984) - i. hábito; j. detalhe da face abaxial dos segmentos e da cóstula. Figure 2 - a-c. Dennstaedtia globulifera (A. Salino 9569) - a. detail of the abaxial surface of segments and costule; b. detail of the adaxial surface of segments and costule; c. detail of petiole base and stem. d-f. Histiopteris incisa (F.C. Assis 01) - d. medial pinna; e. detail of the abaxial surface of segments and costule; f. detail of petiole base and stem. g-h. Hypolepis aquilinaris (J.B. Figueiredo $481)$ - g. detail of the abaxial surface of rachis, costa and pinnules; h. detail of petiole base and stem. i-j. Hypolepis mitis (A. Salino 12984) - i. habit; j. detail of the abaxial surface of segments and costule. 
Dennstaedtia globulifera ocorre nos estados Unidos, América Central, Caribe até a Argentina (Tryon \& Stolze 1989). No Brasil ocorre nos estados do Ceará, Bahia, Mato Grosso do Sul, Minas Gerais, Rio de Janeiro, São Paulo, Paraná, Santa Catarina, Rio Grande do Sul (Schwartsburd 2010) e Espírito Santo (Salino 13486 - BHCB). Em Minas Gerais ocorre geralmente no interior de formações florestais como matas ciliares, florestas estacionais deciduais e semideciduais, e floresta ombrófila densa submontana e montana, entre 450 e $1400 \mathrm{~m}$ de altitude.

3. Histiopteris (J. Agardh) J. Sm., Hist. Fil.: 294. 1875.

Histiopteris é um gênero com distribuição pantropical e temperada, representado por uma ou poucas espécies (Tryon \& Tryon 1982).

3.1. Histiopteris incisa (Thunb.) J. Sm., Hist. Fil.: 295. 1875. Pteris incisa Thunb., Prodr. Pl. Cap.: 171. 1800.

Fig. 2d-f

Plantas terrestres, raro rupícolas; caule longoreptante, 2,04-7,08 mm diâm., com escamas lanceoladas, às vezes filiformes, de ápice acuminado, não ciliadas, subclatradas, piloso ou pubescente com tricomas aciculares e catenados. Folhas (32,5) 48,7-238,5 cm compr.; pecíolo (6)11$70 \times(0,18) \quad 0,25-0,70 \mathrm{~cm}$, sulcado ou não adaxialmente, com escamas lanceoladas, de ápice acuminado a filiforme, não ciliadas, subclatradas, somente na base, ou sem escamas, pubescente com tricomas aciculares ou catenados, ou sem tricomas; lâmina 26,5-166,2 cm compr., 2-pinado-pinatífida a pinatissecta, raro 3-pinada, membranácea a papirácea, elíptica ou lanceolada, ápice agudo ou cuneado; raque geralmente sulcada adaxialmente, pubescente com tricomas catenados ou glabra; pinas $(4,3) 9,2-55,8 \mathrm{~cm}$ compr., sésseis, lanceoladas, elípticas ou lineares, ápice agudo ou cuneadocaudado, glabras; costa sulcada ou não adaxialmente, glabra; pínulas $(0,67) 1,1-14,7 \times 0,39$ $-4 \mathrm{~cm}$, sésseis, lanceoladas, lineares, elípticas ou oblongas, ápice cuneado-caudado, oblongo, ou agudo, as basais reduzidas geralmente no lado basioscópico; cóstula geralmente sulcada adaxialmente; pinululas quando presentes $0,5-2,1$ $\times 0,3-0,72 \mathrm{~cm}$, sésseis, margem inteira ou crenada, recurvada, as basais reduzidas no lado basioscópico; nervuras anastomosadas. Soros oblongos ou lineares nos lados acroscópico e basioscópico; indúsio linear, membranáceo, margem crenada, glabro.

Material examinado selecionado: Camanducaia, mata da nascente do rio Camanducaia, $22^{\circ} 42$ ' 50 "'S e 45 56' 12”'W, 20.VI.2000, A. Salino 5619 (BHCB). Santa Maria do Salto, Fazenda Duas Barras, $16^{\circ} 24^{\prime} 16,5^{\prime \prime} \mathrm{S}$ e 4003'27,4”'W, X.2003, A. Salino et al. 9185 (BHCB). São Gonçalo do Rio Preto, Parque Estadual do Rio Preto, $18^{\circ} 12^{\prime} 02,4^{\prime \prime}$ e e 43 $20^{\prime} 18,4^{\prime \prime}$ 'W, 6.VIII.2003, A. Salino et al. 9321 (BHCB).

Histiopteris incisa ocorre no arquipélago de Juan Fernandez, Sudeste da Ásia, África, Nova Zelândia, Tasmânia, México, América Central, Caribe, Venezuela até a Bolívia (Mickel \& Smith 2004). No Brasil ocorre nos estados da Bahia, Minas Gerais, Rio de Janeiro, São Paulo, Paraná, Santa Catarina e Rio Grande do Sul (Schwartsburd 2010). Em Minas Gerais ocorre em formações florestais e campestres, como campos rupestres, matas de galeria e capões de mata da Cadeia do Espinhaço, florestas estacionais semideciduais montana e altomontana entre 1100 e $1900 \mathrm{~m}$ de altitude.

4. Hypolepis Bernh., Neues J. Bot. (Schrad.) 1(2): 34. 1806.

Segundo Moran (1995), Hypolepis é um dos gêneros menos estudados em pteridófitas e várias espécies deverão ser descritas ainda, sendo necessário um estudo mais abrangente. É composto por aproximadamente 50 espécies e distribui-se nos neotrópicos e regiões temperadas meridionais. As espécies estudadas apresentam caule longo-reptante.

\section{Chave de identificação para as espécies de Hypolepis em Minas Gerais}

1. Pecíolo, raque e costa com espinhos

4.3. H. repens

1. Pecíolo, raque e costa sem espinhos.

2. Pecíolo e lâmina com tricomas glandulares

4.4. H. stolonifera

2'. Pecíolo e lâmina sem tricomas glandulares.

3. Lâmina lanceolada a elíptica; base do pecíolo piloso com tricomas setiformes

3'. Lâmina deltóide; base do pecíolo sem tricomas setiformes 4.2.H. mitis 
4.1. Hypolepis aquilinaris (Fée) Christ, Bull. Boiss. II. 2. 636. 1902. Cheilanthes aquilinaris Fée, Crypt. Vasc. Brés. II: 37. 1872-73.

Fig. 2g-h

Plantas terrestres, raro rupícolas; caule 1,333,17 mm diâm., pubescente com tricomas catenados, piloso ou não com tricomas setiformes, sem estolões. Folhas 15,5-234 cm compr., eretas; pecíolo 4,5-51× 0,04-0,48 cm, sulcado adaxialmente, piloso com tricomas setiformes na base do pecíolo, pubescente com tricomas aciculares e catenados, sem espinhos; lâmina 11-183 cm compr., 2-3-pinado-pinatisecta, raro 4-pinada, membranácea a papirácea, lanceolada a elíptica, ápice agudo a cuneado; raque levemente flexuosa ou não, sulcada adaxialmente, pubescente com tricomas aciculares ou catenados sem espinhos; pinas 3,5-61,1 cm compr., pecioluladas ou sésseis, elípticas ou lanceoladas, ápice cuneado ou agudo; costa sulcada adaxialmente, pubescente, sem espinhos; pínulas 0,89-13×0,41-4,66 cm, sésseis a curto-pecioluladas, lanceoladas, elípticas ou lineares, ápice redondo, cuneado ou agudo, as basais reduzidas ou não; cóstula sulcada adaxialmente, pubescente, sem espinhos; pinululas 0,32-1,52×0,182-0,57 cm, sésseis, lanceoladas, lineares, ovadas, ou elípticas, ápice redondo, cuneado ou agudo, margem crenada, recurvada a plana, as basais reduzidas ou não; nervuras 1(2)-bifurcadas; indumento de tricomas aciculares na costa, cóstula, tecido laminar, nervuras e margens dos segmentos, tricomas catenados na costa e cóstula, tricomas clavados no tecido laminar e nervuras. Soros e indúsio não vistos.

Material examinado selecionado: Aiuruoca, Parque Estadual da Serra do Papagaio, $22^{\circ} 02^{\prime} 32,5^{\prime}$ 'S e 44³8'32,1'W, 19.V.2005, A. Salino \& T.E. Almeida 10476 (BHCB). Santa Maria do Salto, Fazenda Duas Barras, $16^{\circ} 24^{\prime} 16,5^{\prime}$ 'S e 40 03'27,4”'W, 10.X.2003, A. Salino et al. 9238 (BHCB). São Roque de Minas, Parque Nacional da Serra da Canastra, Capão Forro, $20^{\circ} 15^{\prime} 11,9$ "S e 46²4'26,1'”, 31.I.2007, A. Salino et al. 11603 (BHCB).

Todos os materiais estudados de Hypolepis aquilinaris estavam estéreis.

Espécie aparentemente endêmica do Sudeste do Brasil com registros para o estado do Rio de Janeiro (Fée 1873) e Minas Gerais ocorrendo geralmente em áreas de formações florestais que foram queimadas, formações savânicas e campestres do bioma Cerrado, entre 620 e $1700 \mathrm{~m}$ de altitude.

4.2. Hypolepis mitis Kunze, Linnaea 36: 105. 1869 .

Fig. 2i-j

Plantas terrestres; caule 2,6-4,25 mm diâm., piloso ou pubescente com tricomas aciculares ou catenados, sem estolões. Folhas 75-302 cm compr.; pecíolo 38-145 ×0,40-0,57 cm, sulcado adaxial e abaxialmente, piloso com tricomas aciculares e catenados, pubescente com tricomas catenados, sem espinhos; lâmina 37-157 cm compr., 3-pinada a 3-pinado-pinatífida na base, às vezes 4-pinada, papirácea, deltóide, ápice agudo; raque levemente flexuosa na base, sulcada adaxialmente, pubescente com tricomas catenados, sem espinhos; pinas 11,6 $-48,2 \mathrm{~cm}$ compr., pecioluladas, deltóides ou lanceoladas, ápice agudo; costa sulcada adaxialmente, pubescente ou pilosa, sem espinhos; pínulas $(1,94) 6-15 \times(0,57) 1,3-6,6 \mathrm{~cm}$, pecioluladas a sésseis, elípticas a lineares, ápice agudo a cuneado, as basais não reduzidas; cóstula sulcada ou não adaxialmente, pubescente ou pilosa, sem espinhos; pinululas $0,75-3,1 \times 0,18-0,92 \mathrm{~cm}$, pecioluladas a sésseis, lineares, ápice redondo ou agudo a cuneado, as basais não reduzidas; segmentos $0,40-0,55 \times 0,17-0,25 \mathrm{~cm}$, sésseis, lineares, ápice redondo, margem crenada, geralmente plana, glabra, os basais não reduzidos; nervuras geralmente bifurcadas; indumento de tricomas aciculares e catenados na costa, cóstula, nervuras e tecido laminar, ou clavados nas nervuras e tecido laminar. Soros marginais, oblongos ou arredondados, nos enseios ou próximo dele; indúsio membranáceo, margem crenada e pubescente com tricomas aciculares e catenados.

Material examinado: Aiuruoca, Parque Estadual da Serra

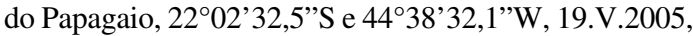
A. Salino \& T.E. Almeida 10502 (BHCB). Alto Caparaó, Parque Nacional do Caparaó, região próxima a Torre

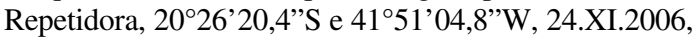
A. Salino et al. 11461 (BHCB). Camanducaia, mata da nascente do rio Camanducaia, $22^{\circ} 42^{\prime} 50^{\prime \prime} \mathrm{S}$ e $45^{\circ} 56^{\prime} 12^{\prime \prime} \mathrm{W}$, 20.VI.2000, A. Salino 5596 (BHCB).

Hypolepis mitis é endêmica do Brasil ocorrendo em Bahia, Minas Gerais, Espírito Santo, São Paulo e Rio de Janeiro (Schwartsburd 2010). Em Minas Gerais ocorre geralmente no interior de formações florestais como floresta estacional semidecidual montana e altomontana, e floresta ombrófila densa montana e altomontana, entre 1000 e $1900 \mathrm{~m}$ de altitude.

4.3. Hypolepis repens (L.) C. Presl, Tent. Pterid. 162. 1836. Lonchitis repens L., Sp. Pl. 2: 1078. 1753.

Fig. 3a-c

Plantas terrestres; caule 1,8-6,2 mm diâm., piloso ou pubescente com tricomas aciculares e catenados, sem estolões. Folhas 66,5-286 cm compr.; pecíolo 24,5$145 \times 0,23-0,71 \mathrm{~cm}$, sulcado adaxialmente, comespinhos, piloso com tricomas aciculares, pubescente com 
tricomas catenados ou aciculares; lâmina 42-157 cm compr., 3-pinado-pinatífida, raro 4-pinada, papirácea a cartácea, raro membranácea, lanceolada a elíptica, ápice cuneado ou agudo; raque não flexuosa, sulcada adaxialmente, com espinhos, pubescente com tricomas catenados; pinas 7,9-49 cm compr., pecioluladas, elípticas a lanceoladas, ápice cuneado ou agudo; costa sulcada adaxialmente, pubescente ou pilosa, com espinhos; pínulas 0,85-9,7×0,51-6,6 cm, pecioluladas a sésseis, lanceoladas, elípticas, ou lineares, ápice cuneado ou redondo, às vezes caudado, as basais reduzidas ou não; cóstula sulcada adaxialmente, pubescente ou pilosa, com ou sem espinhos; pinululas 0,27-3,5 ×0,04-1,19 cm, sésseis ou pecioluladas, lanceoladas, lineares ou ovadas, ápice redondo ou cuneado (nas folhas 4-pinadas), margem geralmente crenada, recurvada, glabra, as basais reduzidas ou não; segmentos 0,5-0,54 ×0,22-0,23 cm, sésseis, lineares, ovados, ou lanceados, ápice redondo ou truncado, os basais não reduzidos; nervuras 1-2-bifurcadas; indumento de tricomas aciculares ou catenados na costa, cóstula, tecido laminar e nervuras, tricomas clavados no tecido laminar e nervuras. Soros marginais, arredondados, oblongos, ou flabelados, nas laterais dos segmentos; indúsio membranáceo, margem crenada, pubescente com tricomas clavados ou aciculares, somente na margem, ou glabro.

Material examinado selecionado: Almenara, Fazenda Limoeiro, $16^{\circ} 04$ '47,1" S e 4050'22,6” W, 29.II.2004, A. Salino et al. 9400 (BHCB). Araponga, Parque Estadual da Serra do Brigadeiro, 26.V.2000, A. Salino et al. 5482 (BHCB). Mariana, Parque Estadual do Itacolomi, Caberão, 20²5'27,2" S e 4328'56,1" W, 13.II.2006, L.B. Rolim \& J.L. Silva 268 (BHCB).

Hypolepis repens apresenta pecíolo com coloração castanho-avermelhada no seu terço inferior.

Esta espécie ocorre nos Estados Unidos, sul do México, América Central, Caribe até a Argentina (Mickel \& Smith 2004). No Brasil, ocorre nos estados do Ceará, Pernambuco, Bahia, Minas Gerais, Rio de Janeiro, São Paulo (Schwartsburd 2010) e Espírito Santo (Salino 13339-BHCB). Em Minas Gerais ocorre em formações florestais e campestres, como campos rupestres quartzíticos e ferruginosos, florestas estacionais semideciduais submontana, montana, altomontana, entre 620 e $1400 \mathrm{~m}$ de altitude.

4.4. Hypolepis stolonifera Fée, Crypt. Vasc. Brés. II: 35. 1872-73.

Fig. 3d-g

Plantas terrestres; caule 1,78 - 4,45 mm diâm., piloso com tricomas aciculares, pubescente com tricomas aciculares, catenados e glandulares, com estolões pilosos com tricomas aciculares ou catenados. Folhas 76-146,7 cm compr.; pecíolo $32-55,8 \times 0,22-0,49 \mathrm{~cm}$, sulcado adaxialmente, piloso com tricomas aciculares, pubescente com tricomas glandulares e catenados, sem espinhos; lâmina 44-102,2 cm compr., 3-pinado-pinatífida, membranácea a levemente papirácea, lanceolada a elíptica, ápice cuneado; raque não flexuosa, sulcada adaxialmente, pubescente com tricomas catenados e glandulares, sem espinhos; pinas 10,5-19 cm compr., pecioluladas, elípticas, ápice cuneado; costa sulcada adaxialmente, pubescente, sem espinhos; pínulas 1,9-3,5 $\times$ 0,55-1,26 cm, sésseis, lineares a elípticas, ápice agudo a redondo, as basais não reduzidas; cóstula sulcada ou não adaxialmente, pubescente, sem espinhos; pinululas 0,35-0,67 $\times 0,16-0,33 \mathrm{~cm}$, sésseis, lineares, ápice arredondado, margem crenada, plana, as basais não reduzidas; nervuras geralmente bifurcada, às vezes 2(3)-bifurcadas; indumento de tricomas glandulares e catenados na costa, cóstula, tecido laminar, nervuras e margens dos segmentos. Soros marginais ou submarginais, redondos, em enseios ou próximo a eles; indúsio membranáceo a papiráceo, com margem crenada, levemente recurvada e pubescente com tricomas glandulares e catenados.

Material examinado: Camanducaia, Sítio do mato, $22^{\circ} 43^{\prime} 18,8^{\prime \prime} \mathrm{S}$ e $45^{\circ} 35^{\prime} 45,4$ " W, 31.III.2001, A. Salino \& L.C.N. Melo 6432 (BHCB). Catas Altas, Parque Natural do Caraça, Pico do Inficcionado, 2008'01,9”'S e 4327'11,2” W, 25.V.2004, A. Salino \& R.C. Mota 9579 (BHCB). Lima Duarte, Parque Estadual do Ibitipoca, 21 ${ }^{\circ} 40^{\prime} 38^{\prime}$ 'S e 4352' 58,3” W, 22.VI.2007, T.E. Almeida et al. 1223 (BHCB).

Hypolepis stolonifera apresenta coloração castanho-acobreada nos eixos.

Esta espécie é aparentemente endêmica do Brasil, com registro para Minas Gerais, Rio de Janeiro, São Paulo, Paraná, Santa Catarina, Rio Grande do Sul (Schwartsburd 2010) e Espírito Santo (Salino 13739 - BHCB). Em Minas Gerais ocorre geralmente nas bordas de formações florestais úmidas (floresta ombrófila densa montana e altomontana), entre 1600 e $2100 \mathrm{~m}$ de altitude.

5. Lindsaea Dryand. ex Sm., Mem. Acad. Roy. Sci 5:413.1793.

O gênero Lindsaea foi revisado por Kramer (1957) e possui ca. 150 espécies com distribuição pantropical e extratropical. As espécies estudadas apresentam caule reptante. 

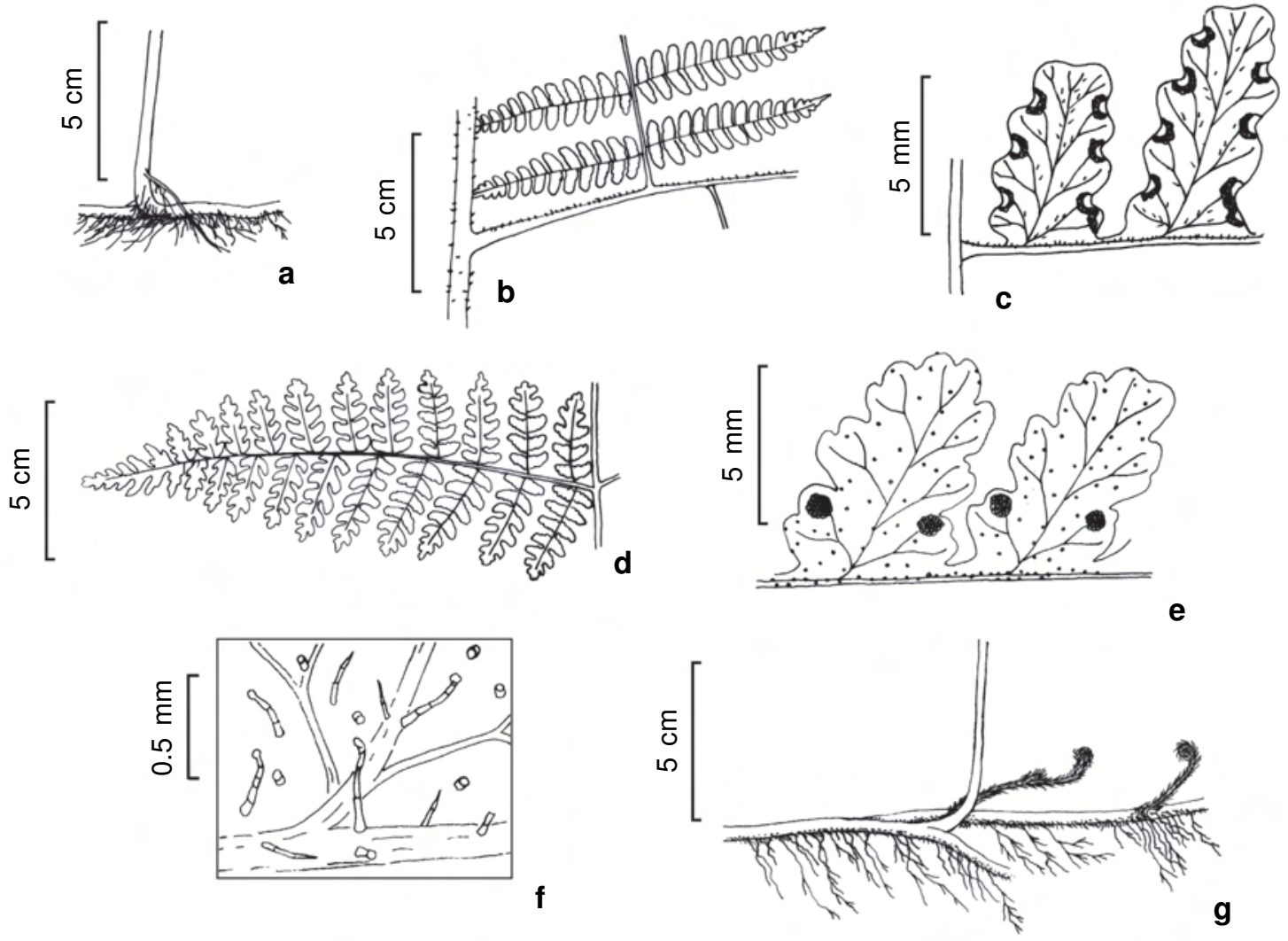

Figura 3 - a-c. Hypolepis repens (J.B. Figueiredo 398) - a. detalhe da base do pecíolo e caule; b. detalhe da face abaxial da raque, costa e pínulas; c. detalhe da face abaxial dos segmentos e da cóstula. d-g. Hypolepis stolonifera (A. Salino 12389) - d. pina mediana; e. detalhe da face abaxial dos segmentos e da cóstula; f. detalhe da face abaxial do segmento, mostrando tricomas glandulares; g. detalhe da base do pecíolo e caule com estolões.

Figure 3 - a-c. Hypolepis repens (J.B. Figueiredo 398) - a. detail of petiole base and stem; b. detail of the abaxial surface of rachis, costa and pinnules; c. detail of the abaxial surface of segments and costule. d-g. Hypolepis stolonifera (A. Salino 12389); d. medial pinna; e. detail of the abaxial surface of segments and costule; f. detail of the abaxial surface of segment showing glandular trichomes; g. detail of petiole base and stem showing stolons.

\section{Chave de identificação para as espécies de Lindsaea em Minas Gerais}

1. Lâmina 1-2 pinada, raro 3-pinada.

2. Pinas (lâmina 1-pinada) ou pínulas (lâmina 2-pinada) medianas flabeladas a ovadas.

3. Lâmina 1-pinada, raro 2-pinada; margem do indúsio crenada ou ondulada

5.3. L. botrychioides

3'. Lâmina 2-pinada, raro 1-pinada; margem do indúsio fortemente serreada 5.7. L. ovoidea

2'. Pinas (lâmina 1-pinada) ou pínulas (lâmina 2-pinada) medianas dimidiadas.

4. Costa abaxialmente angulada.

5. Pecíolo e raque abaxialmente angulados.

6. Esporos monoletes

5.8. L. quadrangularis ssp. quadrangularis

6'. Esporos triletes

5.6. L. lancea var. lancea

5. Pecíolo e raque abaxialmente cilíndricos 5.4. L. divaricata

4'. Costa abaxialmente cilíndrica.

7. Pínulas até 2,5 vezes mais compridas que largas.

8. Raque com tricomas catenados, pinas $2,5-3,5 \mathrm{~cm}$ larg 
8. Raque sem tricomas catenados, pinas $0,25-2 \mathrm{~cm}$ larg.

5.9. L. stricta var. stricta

7’. Pínulas mais que 2,5 vezes mais compridas que largas 5.1. L. arcuata

1'. Lâmina 2-pinado-pinatífida ou (2)3-pinado-pinatissecta, raro 1-pinado-pinatífida.

9. Último segmento pinatissecto, com ápice bifurcado; pínula basal dividida igualmente às pínulas medianas

9'. Último segmento pinatífido, com ápice não bifurcado; pínula basal mais vezes dividida que as pínulas medianas 5.10. L. virescens var. virescens

5.1. Lindsaea arcuata Kunze, Linnaea 9: 86.1835. Fig. $4 a-c$

Plantas terrestres ou rupícolas; caule 0,95 3,6 mm diâm., com escamas lanceoladas, de ápice acuminado a filiforme, sem tricomas. Folhas 17,5$80,9 \mathrm{~cm}$ compr.; pecíolo $6,5-50,7 \times 0,08-0,35 \mathrm{~cm}$, sulcado ou não adaxialmente, cilíndrico ou angulado abaxialmente, com escamas lanceoladas, de ápice acuminado a filiforme, pubescente com tricomas catenados, clavados, ou sem tricomas; lâmina 10 $33 \mathrm{~cm}$ compr., 2-pinada, raro 1-pinada, membranácea, rombiforme, raro linear, abaxialmente não glauca; raque sulcada, alada ou não adaxialmente, angulada a cilíndrica abaxialmente, pubescente com tricomas catenados ou clavados, ou glabra; pinas 5,7-19×1,1-3,4 cm, pecioluladas, elípticas a lineares, ápice cuneado ou agudo, às vezes caudado, as basais não reduzidas; costa sulcada adaxialmente, cilíndrica abaxialmente, pubescente; pínulas $0,84-2,8 \times 0,33-0,76 \mathrm{~cm}$, pecioluladas, dimidiadas, ápice redondo, agudo ou truncado, margem inteira a crenada, glabra, as basais reduzidas; nervuras (1)2-bifurcadas; indumento de tricomas catenados e clavados na costa e tecido laminar; nervuras glabras. Soros oblongos ou lineares na margem acroscópica, às vezes no ápice das pínulas; indúsio membranáceo a papiráceo com margem ondulada, glabro; esporos triletes.

Material examinado selecionado: Catas Altas, Parque Natural do Caraça, 2005'46”S e 4328'45”'W, 30.VIII.1997, A. Salino 3373 (BHCB). Felício dos Santos, APA Felício, Mata do Isidoro, 18¹1'48, 1'S e 4317'13,7'W, 30.X.2004, A. Salino et al. 9937 (BHCB). Formoso, Parque Nacional do Grande Sertão Veredas, 15²3’26,8'S e 45 53’04,4”'W, 7.II.2006, A. Salino et al. 10801 (BHCB).

Lindsaea arcuata ocorre no México, América Central, Cuba, Hispaniola, Venezuela até a Bolívia (Mickel \& Smith 2004). No Brasil ocorre nos estados de Minas Gerais, São Paulo, Rio de Janeiro e Santa Catarina (Schwartsburd, 2010). Em Minas Gerais ocorre geralmente, em locais muito úmidos, muitas vezes até alagados em matas ciliares e de galeria, floresta estacional semidecidual montana e floresta ombrófila densa montana e altomontana e veredas, entre 750 e $1600 \mathrm{~m}$ de altitude.

5.2. Lindsaea bifida (Kaulf.) Mett. ex Kuhn, Festschr. 50 Jahr. Jub. Real. Berlin 26. 1882. Davallia bifida Kaulf., Enum. 222. 1824.

Fig. 4d-e

Plantas terrestres, raro rupícolas; caule 1,153,13 mm diâm., com escamas lanceoladas, de ápice filiforme, sem tricomas. Folhas $13-41,5 \mathrm{~cm}$ compr.; pecíolo 5,5-24,4×0,05-0,16 cm, sulcado ou alado adaxialmente, cilíndrico a angulado abaxialmente, com escamas lanceoladas, de ápice filiforme, pubescente com tricomas clavados ou sem tricomas; lâmina 7-22 cm compr., 3-pinadopinatissecta, raro 2-pinado-pinatissecta, membranácea, lanceolada a rombiforme, abaxialmente não glauca; raque sulcada adaxialmente, angulada abaxialmente, pubescente com tricomas clavados ou glabra; pinas 1,15-8,5 $\times$ $1,41-1,80 \mathrm{~cm}$, pecioluladas, lanceoladas ou rombiformes, ápice agudo a cuneado, as basais não reduzidas; costa geralmente sulcada adaxialmente, geralmente cilíndrica na base da face abaxial, pubescente ou glabra; pínulas 0,64-1,67 × 0,39 $2,7 \mathrm{~cm}$, pecioluladas, lanceoladas, ápice bifurcado, as basais não reduzidas; pinululas $0,36-0,61 \times 0,12$ $0,34 \mathrm{~cm}$, pecioluladas, ápice bifurcado, margem crenada ou não, glabras, as basais não reduzidas; nervuras 1(2)-bifurcadas; indumento de tricomas clavados na costa e tecido laminar, geralmente tecido laminar e nervuras glabros. Soros oblongos a flabelados no ápice das pínulas e pinululas; indúsio membranáceo com margem crenada, glabro; esporos triletes.

Material examinado selecionado: Carrancas, Serra de

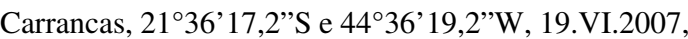
A. Salino et al. 12305 (BHCB). Catas Altas, Parque Natural da Serra do Caraça, Trilha para Gruta do Padre Caio, 15.IV.2000, A. Salino 5245 (BHCB). Simonésia,

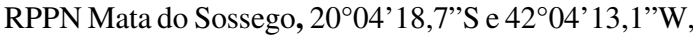
23.V.2006, A. Salino et al. 11174 (BHCB). 
Lindsaea bifida ocorre apenas no Brasil, com registros para os estados da Bahia, Minas Gerais, Espírito Santo, Rio de Janeiro, São Paulo, Paraná e Santa Catarina (Kramer 1957). Em Minas Gerais ocorre geralmente, em locais muito úmidos, muitas vezes até alagados, em matas ciliares, floresta estacional semidecidual e floresta ombrófila densa altomontana, entre 770 e $1700 \mathrm{~m}$ de altitude.

5.3. Lindsaea botrychioides St. Hil., Voy. Distr. Diam. 1:379.1833.

Fig. $4 \mathrm{f}$

Plantas terrestres; caule 0,94-2,09 mm diâm., com escamas lanceoladas, de ápice filiforme, pubescente com tricomas catenados ou clavados, ou sem tricomas. Folhas 30,8-59,1 cm compr.; pecíolo $08,9-22,4 \times 0,07-0,22 \mathrm{~cm}$, geralmente sulcado adaxialmente e angulado abaxialmente, com escamas lanceoladas, de ápice filiforme, pubescente com tricomas catenados ou clavados; lâmina 17,3-38,2 cm compr., 1-pinada, raro 2-pinada, membranácea ou papirácea, linear (1-pinada) ou rombiforme, abaxialmente não glauca; raque sulcada adaxialmente com sulco interrompido pelo peciólulo das pinas, levemente angulada abaxialmente, pubescente com tricomas catenados ou clavados; pinas 0,97-2,1(22,7 nas folhas 2-pinadas) $\times 0,63-1,8 \mathrm{~cm}$, pecioluladas, redondas, flabeladas (1-pinada) ou lineares (2pinada), ápice redondo ou cuneado, as basais não reduzidas; costa sulcada ou não adaxialmente, pubescente; pínulas quando presentes $0,78-0,93 \times$ $0,55-0,58 \mathrm{~cm}$, pecioluladas, flabeladas, ápice redondo, margem fértil inteira a levemente crenada, estéril crenada, as basais reduzidas ou não, glabras; nervuras 2-3-bifurcadas; indumento de tricomas catenados, clavados ou aciculares, na costa. Soros lineares na margem acroscópica; indúsio membranáceo ou papiráceo, com margem crenada ou ondulada, glabro; esporos triletes.

Material examinado selecionado: Barbacena, do lado da Cabana da Mantiqueira na BR 040, XII.2002, A. Salino \& V.A.O. Dittrich 8223 (BHCB). Catas Altas, Parque Natural do Caraça, $20^{\circ} 06^{\prime} 32^{\prime \prime} S$ e $43^{\circ} 28^{\prime} 43^{\prime \prime W}$, 19.IV.1997, A. Salino 3018 (BHCB). Lima Duarte, Parque Estadual do Ibitipoca, $21^{\circ} 42^{\prime} 24^{\prime \prime} \mathrm{S}$ e $43^{\circ} 53^{\prime} 25^{\prime \prime} \mathrm{W}$, 9.VIII.2005, C.M. Mynssen et al. 780 (RB).

Lindsaea botrychioides é uma espécie endêmica do Brasil ocorrendo em Minas Gerais, Rio de Janeiro, São Paulo, Paraná e Santa Catarina (Schwartsburd 2010). Em Minas Gerais ocorre geralmente no interior de formações florestais como floresta ombrófila densa altomontana e floresta estacional semidecidual montana, entre 1200 e $1850 \mathrm{~m}$ de altitude.
5.4. Lindsaea divaricata Klotzsch, Linnaea 18: 547. 1844.

Fig. 4g-i

Plantas terrestres ou rupícolas; caule 1,27-3,89

$(7,17) \mathrm{mm}$ diâm., com escamas lanceoladas, de ápice acuminado a filiforme, pubescente com tricomas aciculares ou catenados, ou sem tricomas. Folhas 12,896,1 cm compr.; pecíolo 8,5-55,7×0,10-0,34 cm, alado ou não, sulcado ou não adaxialmente, cilíndrico abaxialmente, com escamas lanceoladas, de ápice filiforme, pubescente com tricomas clavados, aciculares ou catenados, ou sem tricomas; lâmina 14,340,4 $(50,4) \mathrm{cm}$ compr., 2-pinada, membranácea a papirácea, rombiforme ou linear, abaxialmente glauca ou não; raque alada adaxialmente, não sulcada, cilíndrica abaxialmente, pubescente com tricomas aciculares, catenados, ou clavados, ou glabra; pinas 9-19,3 $\times 1,5-3,2 \mathrm{~cm}$, pecioluladas ou curtopecioluladas, elípticas a lineares, ápice cuneadolanceado, agudo-lanceado, ou truncado, raro caudado, as basais não reduzidas; costa alada, não sulcada, angulada abaxialmente, pubescente ou glabra; pínulas $0,68-1,49 \times 0,3-0,63 \mathrm{~cm}$, curto-pecioluladas a pecioluladas, dimidiadas, ápice redondo a truncado, margem inteira ou crenada principalmente no ápice, glabras, as basais levemente reduzidas a flabeladas; nervuras 1-2-bifurcadas; indumento de tricomas clavados na costa e tecido laminar, ou tecido laminar glabro, nervuras glabras. Soros lineares na margem acroscópica, às vezes no ápice das pínulas; indúsio membranáceo a papiráceo com margem ondulada a crenada, glabro; esporos triletes.

Material examinado selecionado: Carmópolis de Minas, Estação Ecológica Mata do Cedro, 20²7'30,5"S e 44³7'21,2”'W, 11.XII.2004, T.E. Almeida 33 (BHCB). Chapada Gaúcha, Parque Nacional do Grande Sertão Veredas, $15^{\circ} 23^{\prime} 39,4^{\prime \prime}$ 'S e $45^{\circ} 54^{\prime} 01,9^{\prime \prime} \mathrm{W}, 8 . I I .2006, A$. Salino et al. 10802 (BHCB). Santa Rita do Itueto, Parque Estadual de Sete Salões, $19^{\circ} 16^{\prime} 42^{\prime \prime} \mathrm{S}$ e $41^{\circ} 22^{\prime} 22,6^{\prime \prime} \mathrm{W}$, 9.V.2006, A. Salino et al. 10987 (BHCB).

Lindsaea divaricata ocorre na Guatemala, Panamá, Guiana Francesa até o Paraguai (Kramer 1957). No Brasil ocorre nos estados do Amazonas, Mato Grosso, Goiás, Distrito Federal, Minas Gerais e São Paulo (Assis \& Salino 2007). Em Minas Gerais ocorre preferencialmente em matas ciliares e de galeria, em terrenos brejosos ou periodicamente alagados, às vezes, em floresta estacional semidecidual de encosta, ou submontana, entre 600 e $1300 \mathrm{~m}$ de altitude.

5.5. Lindsaea guianensis ssp. lanceastrum K.U. Kramer, Acta Bot Neerl. 6: 216. $1957 . \quad$ Fig. 5a-b

Plantas terrestres; caule 0,95-3,51 mm diâm., com escamas lanceoladas, de ápice filiforme, sem tricomas. Folhas 23,4-77,7 cm compr.; pecíolo 5,6-44,7 $\times 0,14$ 

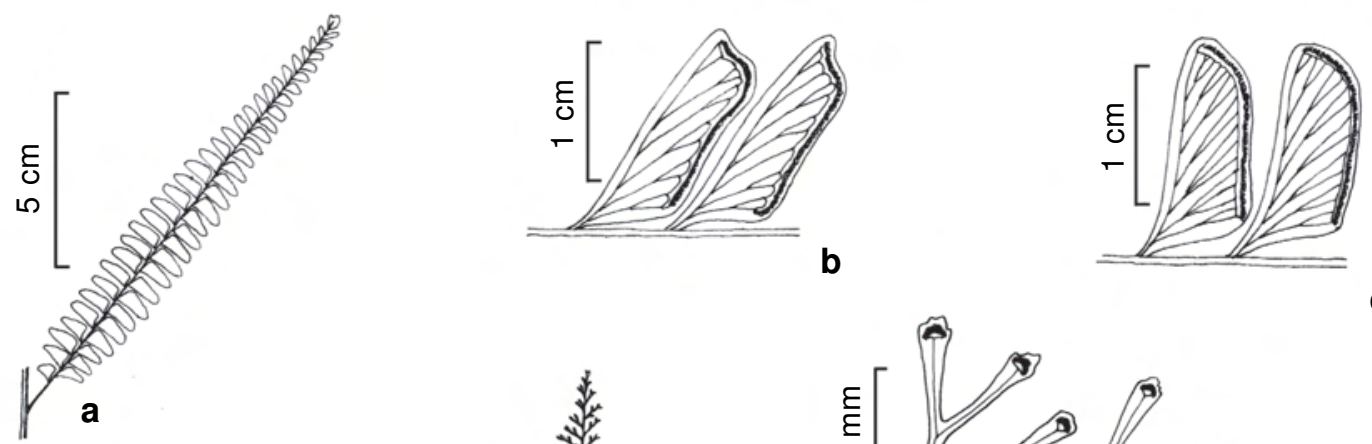

b

C
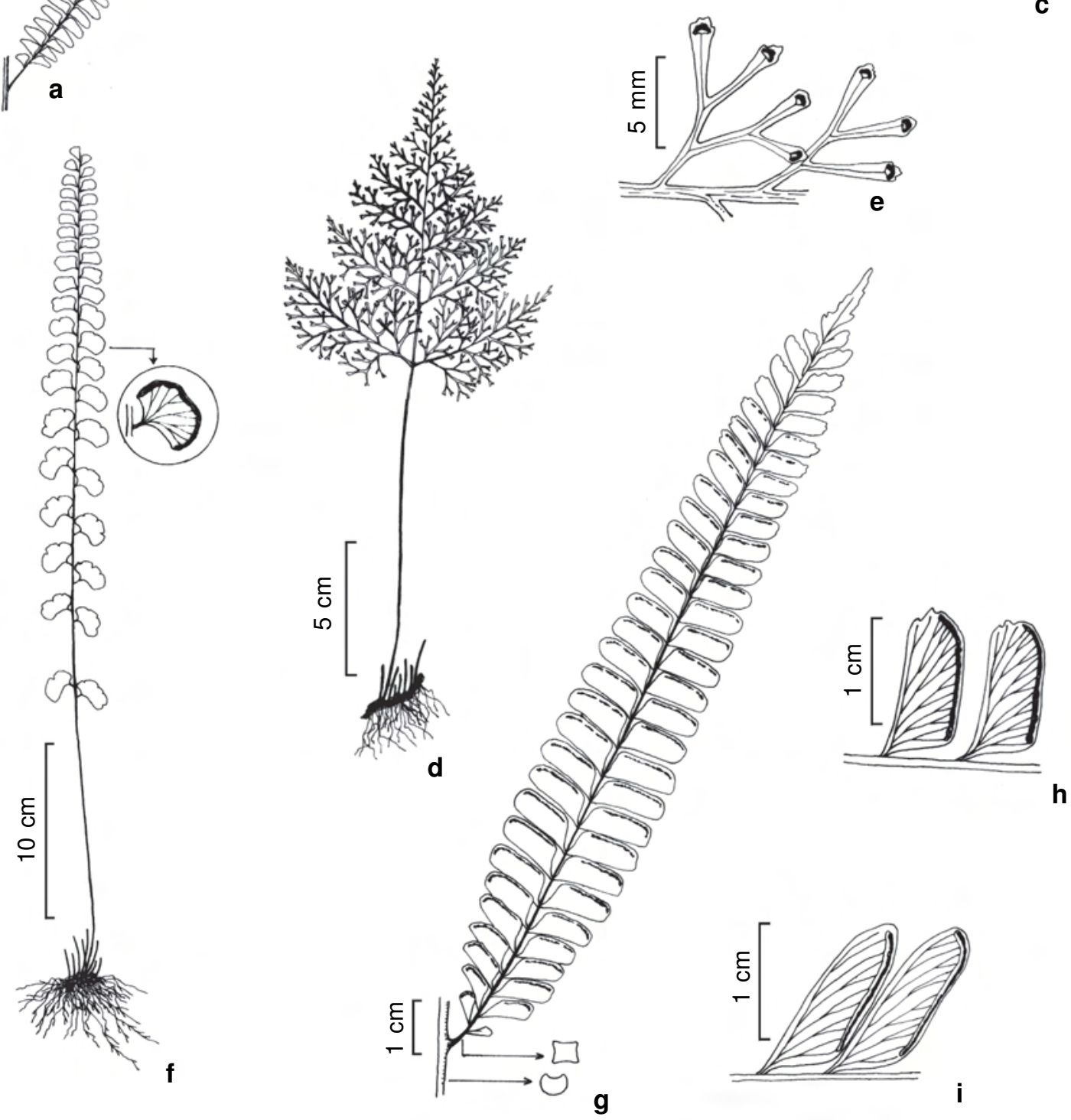

Figura 4 - a-c Lindsaea arcuata - a. pina mediana (A. Salino 5254); b-c. detalhe da face abaxial das pínulas (A. Salino 10988, 5254). d-e. Lindsaea bifida (J.B. Figueiredo 66) - d. hábito; e. detalhe da face abaxial dos segmentos; f. Lindsaea botrychioides (A. Salino 3018) - hábito e detalhe da face abaxial da pina. g-i. Lindsaea divaricata - g. pina mediana; detalhe da forma da raque e costa em corte transversal (A. Salino 10802); h-i. detalhe da face abaxial das pínulas (A. Salino 10860, 8852).

Figure 4 - a-c. Lindsaea arcuata - a. medial pinna (A. Salino 5254); b-c. detail of the abaxial surface of pinnules (A. Salino 10988, 5254). d-e Lindsaea bifida (J.B. Figueiredo 66) - d. habit; e. detail of the abaxial surface of segments. f. Lindsaea botrychioides (A. Salino 3018) - habit and detail of the abaxial surface of pinna. g-i. Lindsaea divaricata - g. medial pinna, and details of the cross sections of rachis and costa (A. Salino 10802); h-i. detail of the abaxial surface of pinnules (A. Salino 10860, 8852). 
$0,27 \mathrm{~cm}$, não sulcado, angulado a cilíndrico abaxialmente, com escamas lanceoladas, de ápice filiforme, pubescente com tricomas clavados ou catenados; lâmina 17,8-37,3 cm compr., 2-pinada, raro 1-pinada, membranácea ou papirácea, rombiforme ou elíptica, abaxialmente não glauca; raque alada ou não adaxialmente, não sulcada, cilíndrica abaxialmente, pubescente com tricomas clavados ou catenados; pinas (13) $10-23,5 \times 2,5-3,5 \mathrm{~cm}$ (pinas 1,13-1,62 ×0,61$0,75 \mathrm{~cm}$ nas plantas 1-pinadas), pecioluladas, elípticas a lineares, ápice cuneado a lanceado, as basais não reduzidas; costa alada ou não, não sulcada, cilíndrica abaxialmente, pubescente ou glabra; pínulas $0,53-1,82$ $\times 0,34-0,73 \mathrm{~cm}$, pecioluladas, dimidiadas, ápice redondo ou truncado, margem inteira a levemente ondulada, ou crenada no lado acroscópico, as basais reduzidas; nervuras 1-2-bifurcadas; indumento de tricomas aciculares ou catenados na costa, tricomas clavados na costa e tecido laminar, ou tecido laminar glabro, nervuras glabras. Soros lineares na margem acroscópica e ápice das pínulas; indúsio membranáceo, com margem ondulada a crenada, glabro; esporos triletes.

Material examinado selecionado: Francisco Dumont, Serra do Cabral, 18.V.2001, G. Hatschbach et al. 72184 (BHCB). Leme do Prado, Estação Ecológica de Acauã, 1709'42,8"S e $42^{\circ} 46$ '38,3’'W, 2.VII.2006, A. Salino et al. 11208 (BHCB). São Roque de Minas, Estrada para a Cachoeira dos Rolinhos, 21.XI.1995, J.N. Nakajima et al. 1573 (BHCB).

Lindsaea guianensis ssp. lanceastrum ocorre no Brasil e Paraguai (Kramer 1957). No Brasil ocorre nos estados do Amazonas, Maranhão, Ceará, Pernambuco, Alagoas, Bahia, Mato Grosso, Goiás, Distrito Federal, Minas Gerais, São Paulo e Paraná (Assis $\&$ Salino 2007). Em Minas Gerais ocorre geralmente em locais encharcados no interior de matas ciliares, de galeria e veredas, entre 700 e $1150 \mathrm{~m}$ de altitude.

5.6. Lindsaea lancea (L.) Bedd. var. lancea, Suppl. Ferns S. Ind. 6.1876. Adiantum lancea L., Sp. Pl. ed.2. 2: 1557.1763.

Fig. $5 \mathrm{c}-\mathrm{d}$

Plantas terrestres; caule 1,19-4,8 mm diâm., com escamas lanceoladas, de ápice acuminado a filiforme, sem tricomas. Folhas $22,2-89,8 \mathrm{~cm}$ compr.; pecíolo $6,5-60,8 \times 0,12-0,32 \mathrm{~cm}$, sulcado ou não adaxialmente, angulado abaxialmente, com escamas lanceoladas, de ápice acuminado a filiforme, pubescente com tricomas clavados, catenados, ou sem tricomas; lâmina 7-34,7 cm compr., 2-pinada, raro 1-pinada, membranácea, rombiforme ou linear, abaxialmente não glauca; raque sulcada ou alada adaxialmente, angulada abaxialmente, pubescente com tricomas clavados, ou glabra; pinas $7-23,5 \times 2-3,9 \mathrm{~cm}$ (pinas 1,28-1,91×0,55-0,84 cm nas plantas 1-pinadas), pecioluladas, elípticas a lineares, ápice lanceado, as basais não reduzidas; costa sulcada ou alada adaxialmente, angulada abaxialmente, pubescente ou glabra; pínulas 1,08-1,95 $\times 0,4-0,88 \mathrm{~cm}$, pecioluladas, dimidiadas, ápice redondo a truncado, margem inteira a crenada, principalmente no ápice das pínulas estéreis, as basais reduzidas (flabeladas); nervuras 1-2-bifurcadas; indumento de tricomas clavados na costa e tecido laminar, ou tecido laminar glabro, nervuras glabras. Soros lineares na margem acroscópica, às vezes no ápice das pínulas; indúsio membranáceo a papiráceo com margem ondulada, glabro; esporos triletes.

Material examinado selecionado: Caratinga, Estação Biológica de Caratinga, 25.III.2000, A. Salino 5165 et al. (BHCB). Santa Maria do Salto, Fazenda Duas Barras, $16^{\circ} 24^{\prime} 18,7$ 'S e $40^{\circ} 03$ '22,1'W, 22.VIII.2003, J.A. Lombardi et al. 5381 (BHCB). São Roque de Minas, Parque

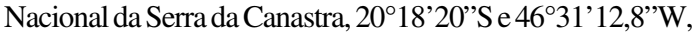
14.VII.1997, A. Salino 3207 (BHCB).

Lindsaea lancea var. lancea ocorre no México, America Central, Antilhas, Trinidad, Guiana Francesa até o Paraguai (Kramer 1957). No Brasil ocorre nos estados do Acre, Rondônia, Amazonas, Amapá, Pará, Ceará, Pernambuco, Alagoas, Bahia, Goiás, Distrito Federal, Mato Grosso, Minas Gerais, Espírito Santo, Rio de Janeiro, São Paulo, Paraná, Santa Catarina e Rio Grande do Sul (Assis \& Salino 2007). Em Minas Gerais ocorre geralmente nas formações florestais do bioma Cerrado, estacionais semideciduais montana e submontana, e ombrófilas densa submontana e montana do bioma Mata Atlântica, entre 250 e $1360 \mathrm{~m}$ de altitude.

\subsection{Lindsaea ovoidea Fée, Crypt. Vasc. Brés. II:} 21. 1872-73.

Fig. 5e-f

Plantas terrestres ou rupícolas; caule 1,251,61 mm diâm., com escamas lanceoladas, de ápice filiforme, sem tricomas. Folhas 12,1-51,8 cm compr.; pecíolo 4,3-21,5× 0,06-0,19 cmm, sulcado ou não adaxialmente, cilíndrico ou angulado abaxialmente, com escamas lanceoladas, de ápice filiforme, pubescente com tricomas clavados; lâmina 7,8-30,3 cm compr., (1)2-pinada, membranácea a papirácea, rombiforme, abaxialmente não glauca; raque sulcada ou não adaxialmente, angulada abaxialmente, pubescente com tricomas clavados ou catenados, ou glabra; pinas 9-12,7 ×1,09-2,16 cm, subsésseis, lineares, ápice cuneado a redondo, as basais não reduzidas; costa sulcada adaxialmente, angulada a cilíndrica abaxialmente, pubescente ou glabra; pínulas $0,68-0,7 \times 0,42-0,45 \mathrm{~cm}$, subsésseis a pecioluladas, flabeladas a ovadas, ápice redondo, margem crenada a serreada, glabra, as basais 

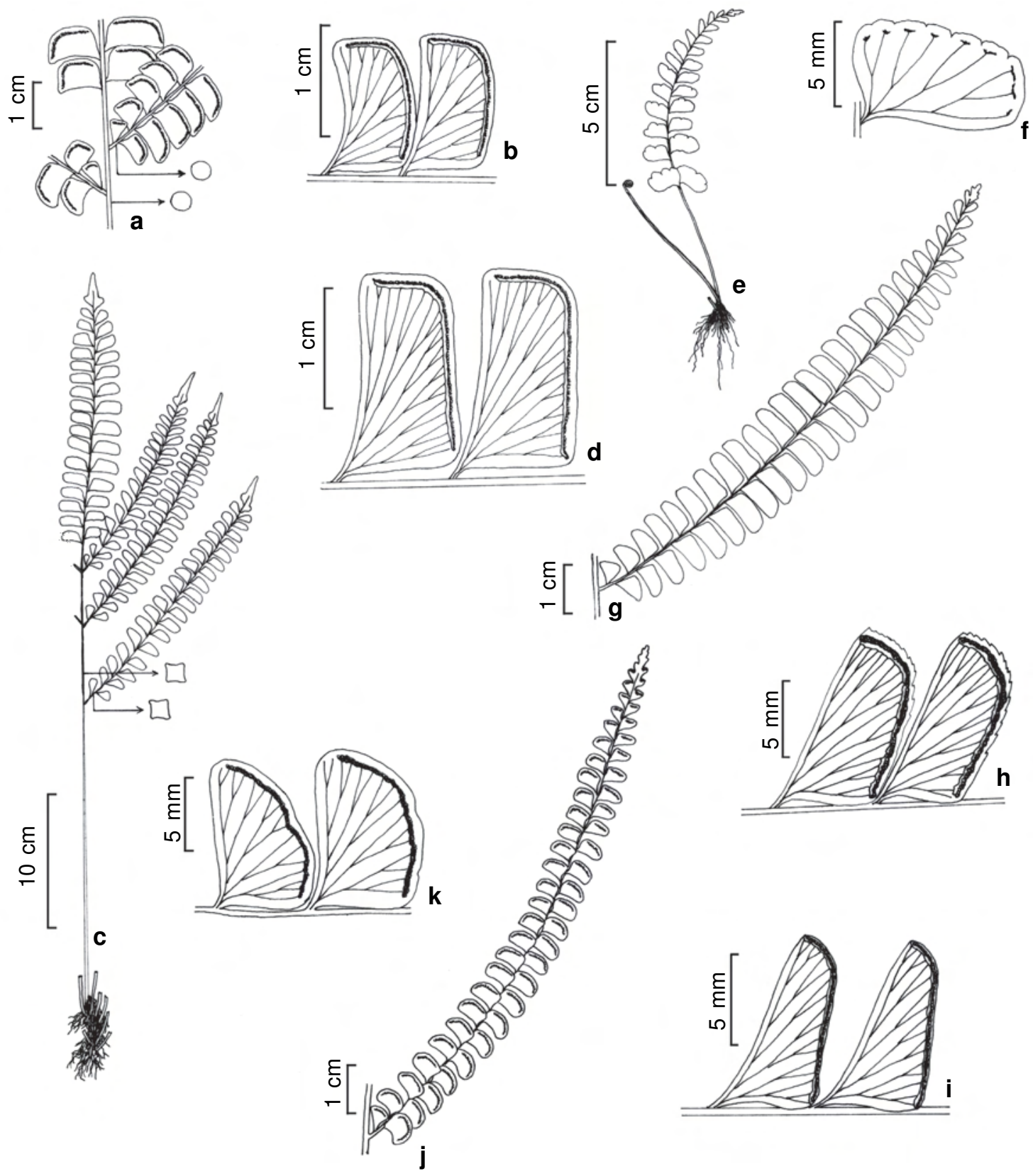

Figura 5-a-b Lindsaea guianensis ssp. lanceastrum (A. Salino 11208) - a. face abaxial das pínulas basais, detalhe da forma da raque e costa em corte transversal; b. detalhe da face abaxial das pínulas. c-d. Lindsaea lancea var. lancea (A. Salino 10896) -c. hábito, mostrando detalhe da forma da raque e costa em corte transversal; d. detalhe da face abaxial das pínulas. e-f. Lindsaea ovoidea (A. Salino 4236) - e. hábito; f. detalhe da face abaxial da pina. g-i. Lindsaea quadrangularis ssp.quadrangularis - g. pina mediana (T.E. Almeida 57); h. detalhe da face abaxial das pínulas (F.A. Carvalho 118); i. detalhe da face abaxial das pínulas (J.B. Figueiredo 285). j-k. Lindsaea stricta var. stricta (A. Salino 3229) - j. pina mediana; k. detalhe da face abaxial das pínulas.

Figure 5 - a-b. Lindsaea guianensis ssp. lanceastrum (A. Salino 11208) - a. abaxial surface of proximal pinnules and detail of the cross section of rachis and costa; b. detail of the abaxial surface of pinnules. c-d. Lindsaea lancea var. lancea (A. Salino 10896); c. habit, and details of the cross sections of rachis and costa; d. detail of the abaxial surface of pinnules. e-f. Lindsaea ovoidea (A. Salino 4236) e. habit; f. details of the abaxial surface of pinna. g-i. Lindsaea quadrangularis ssp. quadrangularis - g. medial pinna (T.E. Almeida 57); h. detail of the abaxial surface of pinnules (F.A. Carvalho 118); i. detail of the abaxial surface of pinnules (J.B. Figueiredo 285). j-k. Lindsaea stricta var. stricta (A. Salino 3229) - j. medial pinna; k. detail of the abaxial surface of pinnules. 
reduzidas ou não; nervuras 2-bifurcadas, às vezes, 1-furcadas; indumento de tricomas clavados na costa e tecido laminar, raro nas nervuras. Soros oblongos ou lineares na margem acroscópica e ápice das pínulas; indúsio membranáceo, com margem fortemente serreada, glabro; esporos triletes.

Material examinado: Ouro Preto, Parque Estadual do Itacolomi, Pico do Itacolomi, 13.V.1998, A. Salino et al. 4236 (BHCB).

Lindsaea ovoidea apresenta pecíolo bege a castanho e uma incisão na porção mediana do lado acroscópico das pínulas.

É uma espécie endêmica do Brasil com registros para Minas Gerais, Rio de Janeiro, São Paulo, Paraná e Santa Catarina (Schwartsburd 2010). Em Minas Gerais ocorre no interior de matas de galeria e de floresta ombrófila densa montana e altomontana, entre 1000 e 1200 m de altitude.

5.8. Lindsaea quadrangularis Raddi ssp. quadrangularis, Opusc. Sci. Bol. 3: 294. 1819.

Fig. 5g-i

Plantas terrestres, raro rupícolas; caule 1,63,99 mm diâm., com escamas lanceoladas, de ápice filiforme, sem tricomas. Folhas 41,2-79 cm compr.; pecíolo $16-50,7 \times 0,09-0,31 \mathrm{~cm}$, alado ou sulcado adaxialmente, angulado abaxialmente, com escamas lanceoladas, de ápice filiforme, pubescente com tricomas clavados, ou sem tricomas; lâmina 20,740,4 cm compr., 2-pinada, membranácea, rombiforme ou linear, abaxialmente não glauca; raque alada, sulcada ou não adaxialmente, angulada abaxialmente, pubescente com tricomas clavados, ou glabra; pinas 7,3-19,6×1,3-2,6 cm, curto-pecioluladas a pecioluladas, lineares, ápice cuneado, caudado ou não, as basais não reduzidas; costa alada ou sulcada adaxialmente, angulada abaxialmente, pubescente ou glabra; pínulas 0,64-1,35×0,34-0,65 cm, curto-pecioluladas, dimidiadas, ápice truncado, margem crenada a fortemente serreada, glabra, as basais reduzidas a flabeladas; nervuras 13-bifurcadas; indumento de tricomas clavados na costa e tecido laminar, ou tecido laminar glabro, nervuras glabras. Soros lineares ou oblongos, na margem acroscópica e ápice das pínulas; indúsio membranáceo com margem crenada a fortemente serreada, pubescente com tricomas clavados, somente na base, ou glabro; esporos monoletes.

Material examinado selecionado: Carangola, Fazenda Santa. Rita, 26.V.1989, A. Salino 737 (BHCB, HB, MBM). Conceição do Mato Dentro, 1906'11,46”S e 4324'33,6”'W, 25.IX.2005, T.E. Almeida et al. 131 (BHCB). Marliéria, Parque Florestal do Rio Doce, IX.1997, A. Salino \& L.C.N. Melo 3443 (BHCB).
Lindsaea quadrangularis ssp. quadrangularis é endêmica do Brasil, com registros para Minas Gerais, Rio de Janeiro, São Paulo e Paraná (Schwartsburd 2010). Em Minas Gerais ocorre geralmente em formações florestais como matas ciliares, de galeria e secundária, e Floresta Estacional Semidecidual Montana, entre 600 e $780 \mathrm{~m}$ de altitude.

5.9. Lindsaea stricta ( $\mathrm{Sw}$.) Dryand. var. stricta, Trans. Linn. Soc. London 3: 42. 1797. Adiantum strictum Sw., Prodr.: 135. $1788 . \quad$ Fig. $5 \mathrm{j}-\mathrm{k}$

Plantas terrestres ou rupícolas, raro epífitas; caule 1,04-4,25 mm diâm., com escamas lanceoladas, de ápice filiforme, sem tricomas. Folhas 8,9-103,8 cm compr.; pecíolo 1,3-61,1 × 0,07-0,33 cm, sulcado ou não adaxialmente, cilíndrico abaxialmente, com escamas lanceoladas, de ápice filiforme, pubescente com tricomas clavados, catenados, ou sem tricomas; lâmina 7,3-55 cm compr., geralmente 2pinada, raramente 1-pinada ou 3-pinada, papirácea a cartácea, rombiforme ou linear, abaxialmente não glauca; raque sulcada ou não adaxialmente, cilíndrica abaxialmente, pubescente com tricomas clavados, ou glabra; pinas $0,39-25,7 \times 0,25-2 \mathrm{~cm}$, curtopecioluladas ou pecioluladas, lineares, elípticas, ou dimidiadas, ápice cuneado, redondo, ou caudado, as basais não reduzidas; costa sulcada ou não adaxialmente, cilíndrica abaxialmente, pubescente ou glabra; pínulas $0,3-1,19 \times 0,23-0,6 \mathrm{~cm}$, curtopecioluladas, dimidiadas ou lineares, ápice redondo ou cuneado, as basais reduzidas ou não; pinululas $0,29-0,64 \times 0,22-0,44 \mathrm{~cm}$, curto-pecioluladas, dimidiadas ou flabeladas, ápice redondo, margem crenada ou ondulada, as basais reduzidas; nervuras 1-2-bifurcadas; indumento de tricomas clavados na costa e tecido laminar, ou tecido laminar glabro, nervuras glabras. Soros lineares ou oblongos, na margem acroscópica e ápice das pínulas; indúsio membranáceo, margem serreada, raro fortemente crenada, pubescente com tricomas clavados, somente na base, ou glabro; esporos triletes.

Material examinado selecionado: Boa Esperança, Parque Estadual da Serra da Boa Esperança, $21^{\circ} 0$ '0,5'S e 4540'40,3'W, 14.XII.2007, A. Salino et al. 13017 (BHCB). Camanducaia, Mata do Trevo de acesso a Camanducaia, 22 44'53,2”S e 4609'16,9'W, 1.VI.2001, A. Salino 6887 (BHCB). Catas Altas, Parque Natural do Caraça, Trilha para a Cascatona, 01.IV.1999, A. Salino et al. 4564 (BHCB).

Kramer (1957) reconheceu para Lindsaea stricta três variedades, sendo que somente $L$. stricta var. stricta ocorre em Minas Gerais. 
Lindsaea stricta var. stricta ocorre no sul do México, América Central, Cuba, Jamaica, Trinidad, Guiana Francesa até a Bolívia (Kramer 1957). No Brasil ocorre nos estados do Acre, Amazonas, Roraima, Amapá, Pará, Rondônia, Maranhão, Pernambuco, Alagoas, Bahia, Goiás, Distrito Federal, Mato Grosso, Minas Gerais, Espírito Santo, Rio de Janeiro, São Paulo, Paraná e Santa Catarina (Assis \& Salino 2007). É a espécie de Lindsaea mais comum em Minas Gerais, ocorrendo em formações campestres, savânicas e florestais do bioma Cerrado e nas florestais estacionais deciduais, e semideciduais do bioma Mata Atlântica, entre 550 e 1600 m de altitude.

5.10. Lindsaea virescens Sw. var. virescens, Kongl. Vetensk. Akad. Handl. 1817: 73. 1817. Fig. 6a-b

Plantas terrestres; caule 1,91-2,39 mm diâm., com escamas lanceoladas, de ápice filiforme, pubescente com tricomas catenados, ou sem tricomas. Folhas 17,5-35,1 cm compr.; pecíolo 9$20,7 \times 0,07-0,13 \mathrm{~cm}$, sulcado adaxialmente, cilíndrico abaxialmente, com ou sem escamas lanceoladas, de ápice filiforme, pubescente com tricomas catenados, ou sem tricomas; lâmina 8,5-14,4 (20) cm compr., 2pinado-pinatífida, raro 1-pinado-pinatífida, membranácea, rombiforme ou lanceolada, abaxialmente não glauca; raque sulcada em ambas as faces, angulada abaxialmente, pubescente com tricomas catenados, ou glabra; pinas 1,5-6,9×1,09$1,51 \mathrm{~cm}$, pecioluladas, lanceoladas, elípticas, ou flabeladas, ápice cuneado, as basais não reduzidas; costa sulcada adaxialmente, angulada abaxialmente, pubescente ou glabra; pínulas 0,74-0,97 ×0,29$0,47 \mathrm{~cm}$, pecioluladas, flabeladas ou dimidiadas, ápice redondo, margem inteira a crenada no ápice, glabra, as basais reduzidas ou não; nervuras 1-2bifurcadas; indumento de tricomas catenados na costa, às vezes tricomas clavados no tecido laminar, geralmente tecido laminar e nervuras glabros. Soros oblongos ou lineares na margem acroscópica das pínulas; indúsio membranáceo, margem ondulada a crenada, glabro; esporos triletes.

Material examinado: Catas Altas, Serra do Caraça, acima da Cascatinha, 2.X.1998, A. Salino 4366 (BHCB). Lima Duarte, Saint Gobain - Fazenda da Serra, 14.VII.2005, E. Tameirão Neto 3932 (BHCB). Ressaquinha, Serra da Trapizonga, VIII.1894, A. Silveira $67(\mathrm{R})$.

Lindsaea virescens apresenta duas variedades, sendo que somente L. virescens $\mathrm{Sw}$ var. virescens ocorre em Minas Gerais.
Espécie endêmica do Brasil, com registros para Minas Gerais, Rio de Janeiro, São Paulo, Paraná, Santa Catarina (Schwartsburd 2010) e Espírito Santo (Kollman 5901 - MBML). Segundo Kramer (1957), ocorre em florestas a ca. $1000 \mathrm{~m}$ de altitude. Em Minas Gerais ocorre no interior de formações florestais como sub-bosque de floresta estacional semidecidual, entre $1000-1300 \mathrm{~m}$ de altitude.

6. Paesia St.-Hil., Voy. Distr. Diam. 1: 381. 1833.

Segundo Tryon \& Stolze (1989), Paesia é um gênero principalmente tropical com ca. 12 espécies, com duas delas na América.

6.1. Paesia glandulosa (Sw.) Kuhn, Festschr 50 Jähr. Jub. Real. Berlin 347 (27). 1882. Cheilanthes glandulosa Sw., Kongl. Vetensk. Akad. Handl. 1817: 77. 1817.

Fig. 6c-e

Plantas terrestres ou rupícolas; caule longoreptante, 1,3-2,95 mm diâm., piloso ou pubescente com tricomas aciculares ou catenados, ou glabro. Folhas 40,6 - $143 \mathrm{~cm}$ compr.; pecíolo 10,9-46,9 $\times$ 0,13-0,25 cm, sulcado ou não adaxialmente, com tricomas aciculares, catenados e glandulares; lâmina 24,3-105,5 cm compr., 3-pinado-pinatífida, às vezes 4-pinado-pinatífida na base, cartácea, elíptica, ápice agudo; raque sulcada adaxialmente, pubescente com tricomas aciculares, catenados e glandulares; pinas 12,5-41,7 cm compr., pecioluladas, lanceoladas ou lineares, ápice cuneado; costa sulcada adaxialmente, pilosa ou pubescente; pínulas $2-6,9 \times 0,7-2 \mathrm{~cm}$, pecioluladas ou sésseis, lanceoladas, lineares, ou elípticas, ápice cuneado, caudado ou não, as basais reduzidas ou não; cóstula sulcada adaxialmente, pilosa, pubescente, ou glabra; pinululas 0,39-0,92 $\times 0,17-0,51 \mathrm{~cm}$, sésseis, lanceoladas, lineares, ovadas, ou dimidiadas, ápice redondo a cuneado, margem inteira e plana, as basais reduzidas ou não; nervuras 1-bifurcadas, às vezes, 2-bifurcadas; indumento de tricomas catenados na costa, cóstula, tecido laminar, margem e nervuras, tricomas glandulares na costa, cóstula e tecido laminar, tricomas aciculares na costa. Soros oblongos; indúsio com margem membranácea e crenada, pubescente com tricomas catenados, aciculares e glandulares, ou glabro, indúsio abaxial presente. Material examinado selecionado: Ouro Preto, Parque Estadual do Itacolomi, 20²4'43,2”S e 43²5'50,1'W, 6.I.2006, L.B. Rolim \& J.L. Silva 163 (BHCB). Rio Preto, Serra do Funil, 21 ${ }^{\circ} 57^{\prime} 50,9$ 'S e 4352'45,7'W, 10.IV.2007, T.E. Almeida et al. 762 (BHCB). Santo Antônio do Itambé, Parque Estadual do Pico do Itambé, 6.X.2006, F.C. Assis et al. 14 (BHCB). 


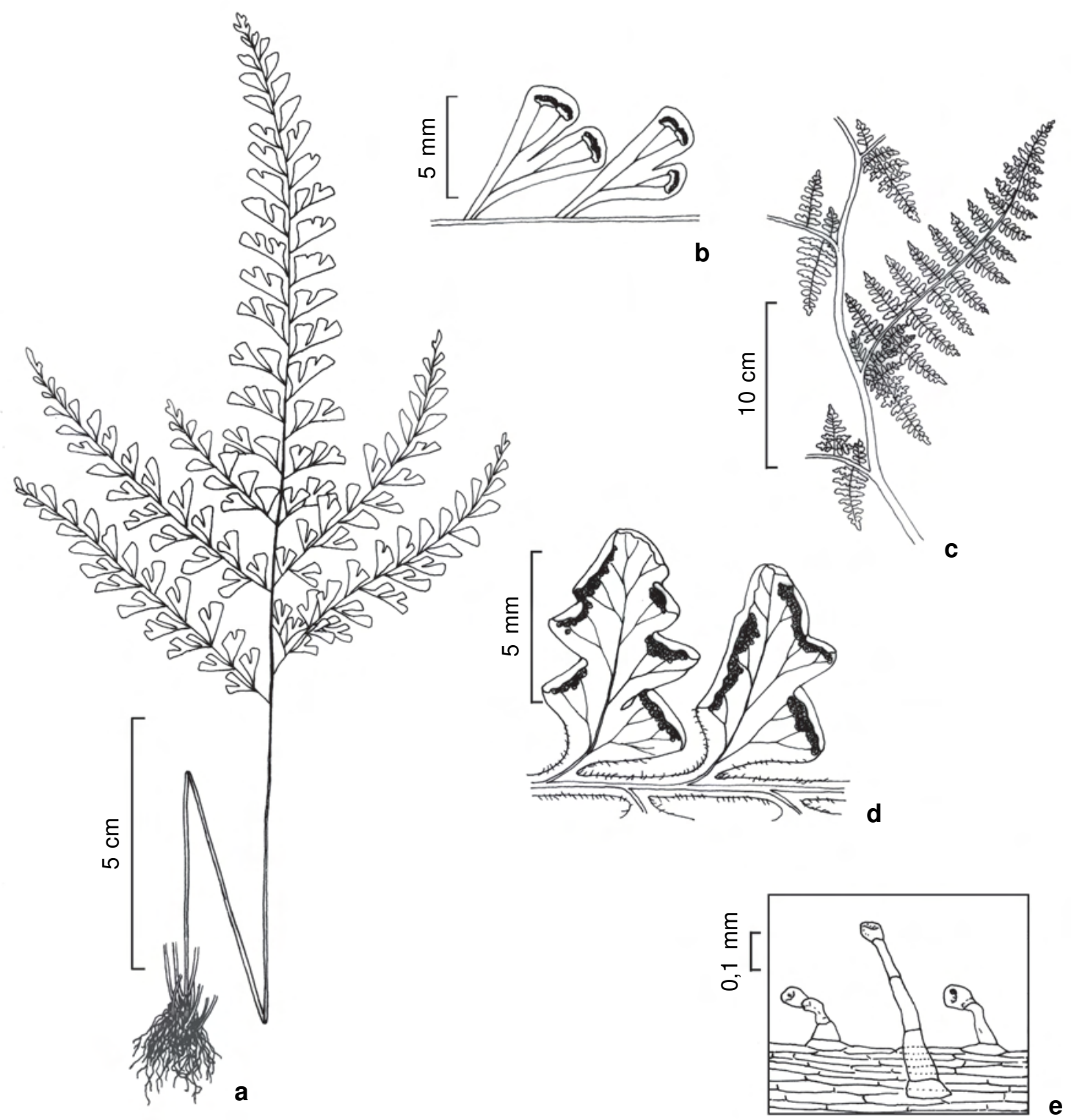

Figura 6 - a-b. Lindsaea virescens var. virescens (E. Tameirão Neto 3932) - a. hábito; b. detalhe da face abaxial das pínulas. c-e. Paesia glandulosa (F.C. Assis 17) - c. Detalhe da face adaxial da raque e pina; d. detalhe da face abaxial dos segmentos; e. tricomas glandulares.

Figure 6 - a-b. Lindsaea virescens var. virescens (E. Tameirão Neto 3932). a. habit; b. detail of the abaxial surface of pinnules. c-e. Paesia glandulosa (F.C. Assis 17) - c. detail of the adaxial surface of rachis and pinna. d. detail of the abaxial surface of segments; e. glandular trichomes.

Paesia glandulosa ocorre na Costa Rica, Panamá, Cuba, Jamaica, Hispaniola, Venezuela até a Bolívia (Tryon \& Tryon 1982). No Brasil ocorre apenas em Minas Gerais (Tryon \& Tryon 1982), no Quadrilátero Ferrífero e Cadeia do Espinhaço, onde ocorre nos campos rupestres e formações florestais montanas e altomontanas, entre $1500 \mathrm{e}$ $1850 \mathrm{~m}$ de altitude.
7. Pteridium Gled. ex Scop., Fl. Carniol. 169. 1760, nom. cons.

Pteridium é um gênero cosmopolita, com ca. 12 espécies. Embora Tryon \& Tryon (1982) tenham considerado apenas uma espécie dividida em 12 variedades, algumas dessas são claramente distintas e merecem reconhecimento em nível específico (Moran 1995, Mickel \& Smith 2004). 
7.1. Pteridium arachnoideum (Kaulf.) Maxon, J. Wash. Acad. Sci. 14: 89. 1924. Pteris arachnoidea Kaulf., Enum. Fil.: 190. 1824.

Fig. 7a-b

Plantas terrestres; caule longo-reptante, 2,82-12,19 mm diâm., piloso ou pubescente com tricomas aciculares e/ou catenados. Folhas 51$343,3 \mathrm{~cm}$ compr.; pecíolo $(2,5) 13-166,5 \times(0,16)$ $0,32-1,26 \mathrm{~cm}$, sulcado ou não adaxialmente, piloso ou pubescente com tricomas catenados ou aciculares, ou glabro; lâmina 29-176,8 cm compr., 3-4-pinada, raro 5-pinada na base a 2-pinada no ápice, cartácea, lanceolada a elíptica, ápice agudo, cuneado ou não; raque sulcada adaxialmente, às vezes abaxialmente, pilosa ou pubescente com tricomas catenados, ou glabra; pinas $(2,8)$ 5,8-124,9 cm compr., pecioluladas ou sésseis, lanceoladas, elípticas, ou lineares, ápice agudo, cuneado ou não; costa sulcada adaxialmente ou em ambas as faces, pubescente ou glabra; pínulas $(0,34) 0,66-37 \times(0,10) 0,22-$ $16,5 \mathrm{~cm}$, pecioluladas ou sésseis, lanceoladas, lineares, ou elípticas, ápice cuneado a agudo, caudado ou não, as basais reduzidas a ausentes no lado acroscópico; cóstula sulcada adaxialmente, pubescente ou glabra; pinululas $0,12-10 \times 0,03-0,52 \mathrm{~cm}$, sésseis, lineares ou lanceoladas, ápice redondo, agudo, ou cuneadocaudado, as basais reduzidas ou não; segmentos $0,54-1,03 \times 0,17-0,36 \mathrm{~cm}$, sésseis, lineares ou lanceados, ápice cuneado ou redondo, margem inteira, recurvada, glabros, os basais reduzidos ou não, lobos presentes ao menos entre os últimos segmentos; nervuras bifurcadas; indumento de tricomas catenados na costa, cóstula e do tecido laminar, setiformes nas nervuras, ou tecido laminar glabro. Soros lineares; indúsio com margem crenada, pubescente com tricomas catenados, indúsio abaxial presente, porém pouco desenvolvido.
Material examinado selecionado: Alto Caparaó, Parque Nacional do Caparaó, XI.2006, A. Salino et al. 11403 (BHCB). Bocaiúvas, Parque Nacional das Sempre

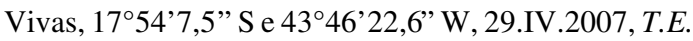
Almeida et al. 926 (BHCB). Carrancas, Serra de

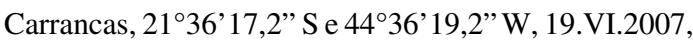
A. Salino et al. 12300 (BHCB).

Foram analisados indivíduos de Pteridium arachnoideum com lâmina 5-pinada, o que ainda não tinha sido descrito para o gênero e para a família. Esta espécie foi tratada por Tryon \& Tryon (1982) como $P$. aquilinum subsp. aquilinum var. arachnoideum (Kaulf.) Brade.

Pteridium arachnoideum ocorre no México, América Central, Grandes Antilhas, Trinidad até o Uruguai (Mickel \& Smith 2004). No Brasil ocorre em Amazonas, Pará, Ceará, Pernambuco, Alagoas, Bahia, Distrito Federal, Mato Grosso do Sul, Minas Gerais, Espírito Santo, Rio de Janeiro, São Paulo, Paraná, Santa Catarina e Rio Grande do Sul (Schwartsburd 2010). Em Minas Gerais Pteridium arachnoideum é comum em beira de estradas, encostas secas e locais úmidos, crescendo em locais abertos, onde a mata original foi cortada, ocorrendo raramente em formações florestais mais abertas. Forma grandes populações. Ocorre também associada a diversas formações vegetacionais como florestas estacionais semideciduais, florestas ombrófilas, e diversas formações campestres e savânicas, entre 450 e $1800 \mathrm{~m}$ de altitude.

8. Saccoloma Kaulf., Berl. Jahrb. Pharm. Verbundenen Wiss. 21: 51. 1820.

Saccoloma é um gênero pantropical (Mickel \& Smith 2004). Segundo Moran (1995) o gênero possui três espécies no neotrópico. As espécies apresentam caule ereto.

\section{Chave de identificação para as espécies de Saccoloma em Minas Gerais}

1. Lâmina 1-pinada; pinas inteiras

8.1. S. elegans

1'. Lâmina 2-3-pinado-pinatífida 8.2. S. inaequale 


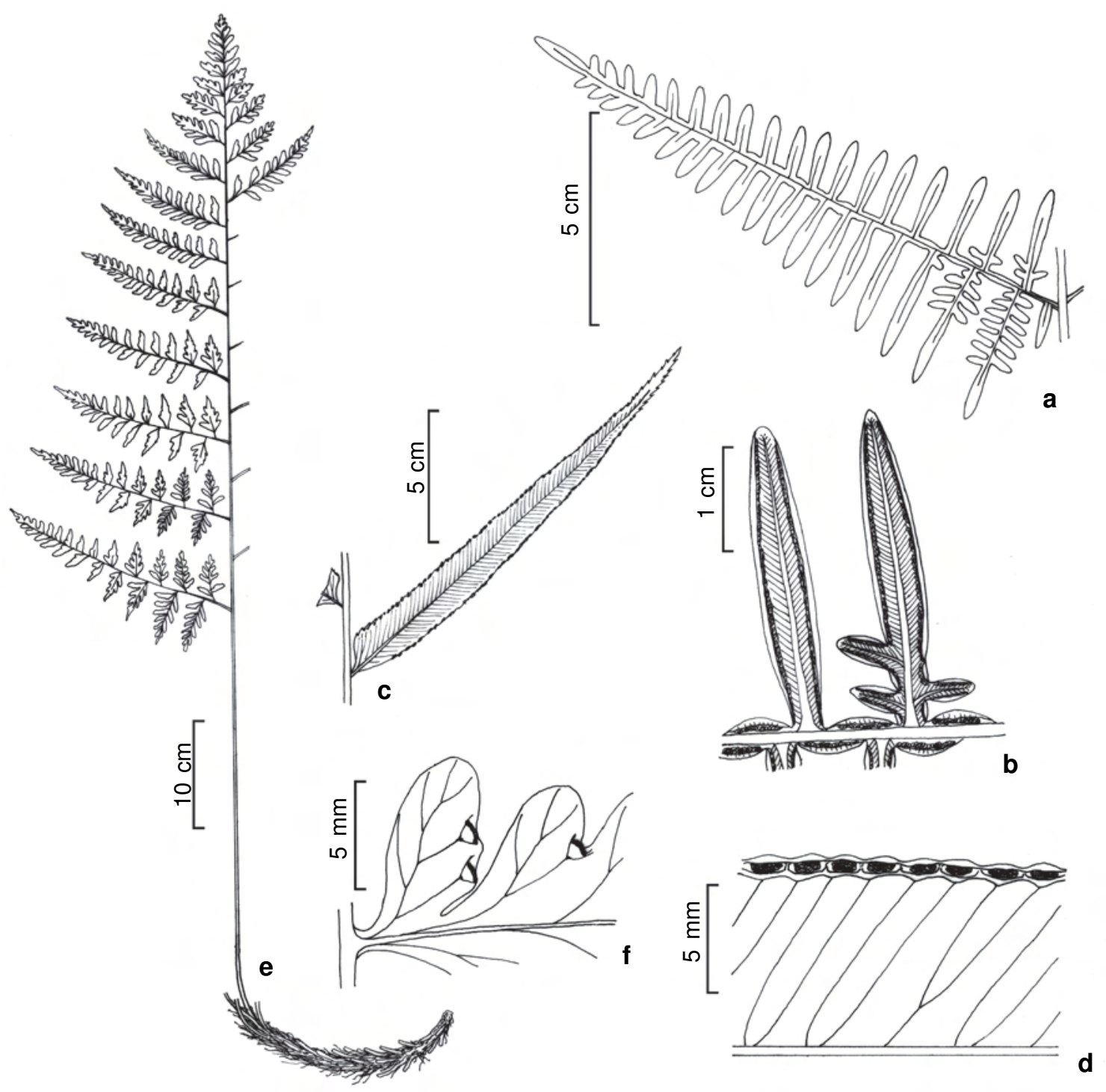

Figura 7 - a-b. Pteridium arachnoideum (F.C. Assis 10) - a. Pina mediana; b. Detalhe da face abaxial dos segmentos. c-d. Saccoloma elegans (A. Salino 8966) - c. Pina mediana; d. Detalhe da face abaxial da pina. e-f. Saccoloma inaequale (A. Salino 8413) - e. Hábito; f. Detalhe da face abaxial dos segmentos.

Figure 7 - a-b. Pteridium arachnoideum (F.C. Assis 10) - a. Medial pinna; b. Detail of the abaxial surface of segments. c-d. Saccoloma elegans (A. Salino 8966) - c. Medial pinna; d. Detail of the abaxial surface of pinna. e-f. Saccoloma inaequale (A. Salino 8413) - e. Habit; f. Detail of the abaxial surface of segments.

8.1. Saccoloma elegans Kaulf., Berlin. Jahrb. Pharm. Verbundenen Wiss. 21:51. $1827 . \quad$ Fig. 7c-d

Plantas terrestres; caule 5,73-17,5(21) mm diâm., com escamas lanceoladas, de ápice acuminado, não ciliadas, não clatradas, piloso com tricomas catenados, ou sem tricomas. Folhas 78,5-208,1 cm compr.; pecíolo 31,5-114 × 0,39-1,34 cm, sulcado adaxialmente, ou em ambas as faces, com ou sem escamas lanceoladas, de ápice acuminado, ciliadas, não clatradas, pubescente com tricomas catenados, ou sem tricomas; lâmina 45-133,1 cm compr., 1pinada, membranácea, elíptica, ápice conforme; raque sulcada adaxialmente, pubescente com tricomas catenados ou aciculares, ou glabra; pinas 12,5-35,2 $\times 1,7-3,2 \mathrm{~cm}$, pecioluladas, lineares a lanceoladas, ápice cuneado, raro caudado, margem crenada; costa sulcada adaxialmente, pubescente ou glabra; nervuras bifurcadas; indumento de tricomas 
catenados na costa, tecido laminar e nervuras glabros. Soros marginais ou submarginais, arredondados ou lineares; indúsio às vezes com margem membranácea, crenada.

Material examinado selecionado: Almenara, Fazenda Limoeiro, 1604'47,1'S e 4050'22,6”'W, 29.II.2004, A. Salino et al. 9392 (BHCB). Barão de Cocais, Mina de Gongo Soco (CVRD), 1956'40,8'’S e 43³6'59'”, 7.V.2003, A. Salino et al. 8697 (BHCB). Tombos, Fazenda da Vargem Alegre, 14.VII.1935, M. Barreto 1601 (BHCB, RB).

Saccoloma elegans ocorre no México, América Central, Grandes Antilhas, Trinidad até a Bolívia (Mickel \& Smith 2004). No Brasil ocorre nos estados de Roraima, Amazonas, Pará, Acre, Rondônia, Pernambuco, Bahia, Minas Gerais, Espírito Santo, Rio de Janeiro, São Paulo, Paraná e Santa Catarina (Schwartsburd 2010). Em Minas Gerais ocorre geralmente no interior de formações florestais como floresta ombrófila densa e floresta estacional semidecidual, e formações campestres como campo rupestre, entre 450 e $1280 \mathrm{~m}$ de altitude.

8.2. Saccoloma inaequale (Kunze) Mett., Ann. Sci. Nat. Bot. sér. 4, 15: 80. 1861. Davallia inaequalis Kunze, Linnaea 9: 87. 1834.

Fig. 7e-f

Plantas terrestres, raro rupícolas; caule 8,5619,44 mm diâm., com escamas lanceoladas, de ápice filiforme, ciliadas, ou glabro. Folhas 91,6-168 cm compr.; pecíolo $38,5-83 \times 0,38-0,80 \mathrm{~cm}$, sulcado adaxialmente, com ou sem escamas lanceoladas, de ápice filiforme, ciliadas, não clatradas, pubescente com tricomas catenados, ou sem tricomas; lâmina 39,6-85 cm compr., 2-3-pinado-pinatífida, membranácea ou papirácea, elíptica, ápice cuneado; raque sulcada adaxialmente, pubescente com tricomas catenados, ou glabra; pinas $14-26,7 \times 5-$ $8,8 \mathrm{~cm}$, pecioluladas, elípticas, lanceoladas, ou lineares, ápice cuneado; costa sulcada adaxialmente, com escamas filiformes, de ápice filiforme, pubescente ou sem tricomas; pínulas 2,2-5 ×0,7$1,4 \mathrm{~cm}$, pecioluladas ou sésseis, geralmente quadrilaterais, ápice cuneado, margem crenada, glabra, as basais reduzidas ou não; nervuras 1-2-bifurcadas, raro 3-bifurcadas; indumento de tricomas catenados ou aciculares na costa, tecido laminar e nervuras glabros. Soros marginais, oblongos ou arredondados; indúsio membranáceo, margem crenada.

Material examinado selecionado: Almenara, Fazenda Limoeiro, $16^{\circ} 02$ 'S e 40 51'W, 22.II.2003, A. Salino et al. 8296 (BHCB). Catas Altas, Serra do Caraça, Fazenda do Engenho, 2002'47,6”'S e 43॰30'13,6”'W, 26.IV.2004, R.C. Mota \& P.O. Morais 2297 (BHCB). Turmalina, Estação Ecológica de Acauã, $17^{\circ} 10 ' 58,2$ 'S e $42^{\circ} 45^{\prime} 58,2$ '”, 3.VII.2006, A. Salino et al. 11253 (BHCB).
Saccoloma inaequale ocorre no sul do México, América Central, Cuba, Porto Rico, Trinidad até a Bolívia (Mickel \& Smith 2004). No Brasil ocorre nos estados do Amazonas, Mato Grosso, Minas Gerais, Rio de Janeiro, São Paulo, Paraná e Santa Catarina (Melo \& Salino 2002). Em Minas Gerais ocorre geralmente no interior de formações florestais como matas de galeria, matas ciliares, em Floresta Estacional Semidecidual e Floresta Ombrófila Densa Submontanas, entre 250 e $1280 \mathrm{~m}$ de altitude.

\section{Agradecimentos}

Agradecemos à Coordenação de Aperfeiçoamento de Pessoal de Nível Superior (CAPES) a concessão de bolsa de Mestrado. À Myrian Morato Duarte, os desenhos que ilustram este trabalho. A todos os pteridólogos do Laboratório de Sistemática Vegetal da Universidade Federal de Minas Gerais (UFMG), o auxílio. Aos curadores dos herbários, o envio das exsicatas.

\section{Referências}

Arantes, A.A.; Prado, J. \& Ranal, M.A. 2008. Monilófitas da Estação Ecológica do Panga, Uberlândia, estado Minas Gerais, Brasil: Dennstaedtiaceae, Dryopteridaceae, Gleicheniaceae, Hymenophyllaceae e Lindsaeaceae. Hoehnea 35: 367-378.

Assis, F.C. \& Salino A. 2007. Dennstaedtiaceae. In: Cavalcanti, T.B. Flora do Distrito Federal. Vol. VI. Embrapa Recursos Genéticos e Biotecnologia, Brasília. Pp. 109-122.

Assis, F.C. 2008. A família Dennstaedtiaceae Pic. Serm. sensu lato (Polypodiopsida) no estado de Minas Gerais, Brasil. Dissertação de Mestrado. Universidade Federal de Minas Gerais. 82p.

Baker, J.G. 1870. Cyatheaceae et Polypodiaceae. In: Martius, C.F.P. \& Eichler, A.G. Flora brasiliensis, Frid. Fleischer, Lipsiae. Vol. 2, pp. 306-624.

Edwards, P.J. 1998. The pteridophytes of the Ilha de Maracá. In: Maracá: The biodiversity and environment of an Amazonian Rainforest. Royal Botanic Gardens, Richmond.

Fée, A.L. 1873. Cryptogames vasculaires du Brésil. V. I. Veuve Berger-Levrault \& Fils. Libraires, Paris.

Holmgren, P.K.; Holmgren, N.H. \& Barnett, L.C. 1990. Index Herbariorum. Part 1. The herbaria of the world. 8 ed. New York Botanical Garden, New York. 693p.

Kieling-Rubio, M.A. \& Windisch, P.G. 2002. O gênero Dennstaedtia Moore (Dennstaedtiaceae, Pteridophyta) no estado do Rio Grande do Sul, Brasil. Pesquisas. Botânica 52: 185-194.

Kramer, K.U. 1957. A revision of the genus Lindsaea in the New World with notes on allied genera. Acta Botanica Neerlandica 6: 97-290. 
Kramer, K.U. 1990. Dennstaedtiaceae. In: Kramer, K.U. $\&$ Green, P.S. The families and genera of vascular plants. Vol. I. Pteridophytes and Gymnosperms. Springer Verlag, New York. Pp. 81-94.

Lellinger, D.B. 2002. A modern multilingual glossary for taxonomic Pteridology. Pteridologia. American Fern Society 3: 1-264.

Matos, F.B. 2009. Samambaias e Licófitas da RPPN Serra Bonita, município de Camacan, sul da Bahia, Brasil. Dissertação de Mestrado. Universidade Federal do Paraná. 237p.

Melo, L.C.N. \& Salino, A. 2002. Pteridófitas de duas áreas de floresta da Bacia do Rio Doce no estado de Minas Gerais, Brasil. Lundiana 3: 129-139.

Mickel, J.T. \& Smith, A.R. 2004. Pteridophytes of Mexico. Memoirs of the New York Botanical Garden 88: 1-1055.

Moran, R.C. 1995. Dennstaedtiaceae. In: Moran, R.C. \& Riba, R. Flora Mesoamericana. Psilotaceae a Salviniaceae. Universidad Nacional Autónoma de México, Ciudad del México. Pp. 150-163.

Mynssen, C.M. \& Windisch P.G. 2004. Pteridófitas da Reserva Rio das Pedras, Mangaratiba, RJ, Brasil. Rodriguésia 55: 125-156.

Pichi Sermolli, R.E.G. 1996. Authors of scientific names in Pteridophyta. Royal Botanic Gardens, Richmond.

Prado, J. 2004a. Pteridófitas do Maciço da Juréia. Estação Ecológica Juréia-Itatins, In: Ambiente físico, flora e fauna. Ribeirão Preto. 139-151.
Prado, J. 2004b. Criptógamas do Parque Estadual das Fontes do Ipiranga, São Paulo, SP. Pteridophyta: 5. Dennstaedtiaceae. Hoehnea 31: 11-22.

Prado, J. 2005. Flora da Reserva Ducke, Amazônia, Brasil: Pteridophyta - Dennstaedtiaceae. Rodriguésia 56: 43-48.

Prado, J. \& Labiak, P.H. 2003. Flora de Grão-Mogol, MG: Pteridófitas. Boletim de Botânica da Universidade de São Paulo. 21: 25-47.

Prado, J. \& Windisch, P.G. 1996. Flora da Serra do Cipó, MG: Dennstaedtiaceae. Boletim de Botânica da Universidade de São Paulo. 15: 83-88.

Sehnem, A. 1972. Pteridáceas. In: Reitz, R. Flora Ilustrada Catarinense. Herbário Barbosa Rodrigues, Itajaí.

Smith, A.R.; Pryer, K.M.; Schuettpelz, E.; Korall, P.; Schneider, H. \& Wolf, P.G. 2006. A classification for extant ferns. Taxon 55: 705-731.

Schwartsburd, P.B. 2010. Dennstaedtiaceae In: Lista de espécies da flora do Brasil. Jardim Botânico do Rio de Janeiro. Disponível em <http://floradobrasil.jbrj. gov.br/2010/FB090917>. Acesso em 24 maio 2010.

Schwartsburd, P.B. \& Labiak, P.H. 2007. Pteridófitas do Parque Estadual de Vila Velha, Ponta Grossa, Paraná, Brasil. Hoehnea 34: 159-209.

Tryon, R. M. \& Stolze, R. G. 1989. Pteridophyta of Peru. Part II. 13. Pteridaceae-15. Dennstaedtiaceae. Fieldiana Botany New Series, 29: 1-128.

Tryon, R.M. \& Tryon, A.F. 1982. Fern and allied plants, with special reference to tropical America. Springer Verlag, New York. 